\title{
Misallocation Before, During and After the Great Recession
}

\author{
Thibault Libert ${ }^{1}$
}

\author{
December 2017, WP \#658
}

\begin{abstract}
This paper assesses resource misallocation dynamics and its impact on aggregate TFP in the French manufacturing sector between 1990 and 2015. I provide an exact decomposition of allocational inefficiency into three components: labor misallocation, capital misallocation, and a third term representing the interplay between both. Misallocation increased substantially between 1997 and 2007, generating a loss in annual TFP growth of roughly 0.8 percentage points. This increase is mainly related to labor misallocation, except at the beginning of the 2000s, when capital misallocation played the leading role. The impact of allocational efficiency during the Great Recession is sizeable: misallocation accounts for roughly $25 \%$ of the 2007-2009 decline in TFP and $20 \%$ of the improvement observed in the immediate aftermath of the crisis. The main feature behind the rise in misallocation during the crisis is the predominance of the interplay component, which is stable the rest of the time. It suggests that one should pay special attention to mechanisms disrupting both labor and capital markets in the wake of financial crises. Finally, allocational efficiency remains rather constant after 2010: the post-crisis slowdown in productivity growth is therefore even more pronounced for efficient TFP than for observed TFP.
\end{abstract}

Keywords: Misallocation; Aggregate Productivity; Great Recession

JEL classification: D24, O11, O47

\footnotetext{
${ }^{1}$ Paris School of Economics - EHESS and Banque de France, thibault.libert@banque-france.fr The author is grateful to Flora Bellone, Christophe Cahn, Fabrizio Coricelli, Carmine Ornaghi and Xavier Ragot for advice and suggestions, and to seminar participants at the Banque de France and at the 2016 AFSE and ESEM annual meetings for helpful comments and discussions. The views expressed in this paper are those of the author and therefore do not necessarily reflect those of the Banque de France or the Eurosystem.

Working Papers reflect the opinions of the authors and do not necessarily express the views of the Banque de France. This document is available on publications.banque-france.fr/en
} 


\section{NON-TECHNICAL SUMMARY}

This paper aims at assessing the loss in aggregate total factor productivity (TFP) that stems from misallocation of factors of production. More generally, this study contributes to the literature relating the dynamics of macro-productivity to determinants at the firm level before, during or after economic crises.

Aggregate TFP obviously depends on micro-productivity, i.e. on the efficiency with which individual firms use their inputs (here labor and capital) in order to produce. However, it also depends on the allocation of these inputs: if one was able to freely reallocate one unit of input from a low-productivity firm to a high-productivity firm, total output would increase while the total stocks of inputs would remain unchanged. Such reallocation would therefore improve aggregate TFP. As a result the dynamics of macro-productivity over time may reflect either changes in micro-productivity or changes in allocational efficiency (also called misallocation). This paper uses recent methodologies to disentangle these two effects. To go further it also decomposes misallocation into three components: the allocational efficiency of labor, the allocational efficiency of capital, and the interplay between both kinds of misallocation.

\section{Evolution of misallocation in the French manufacturing sector}

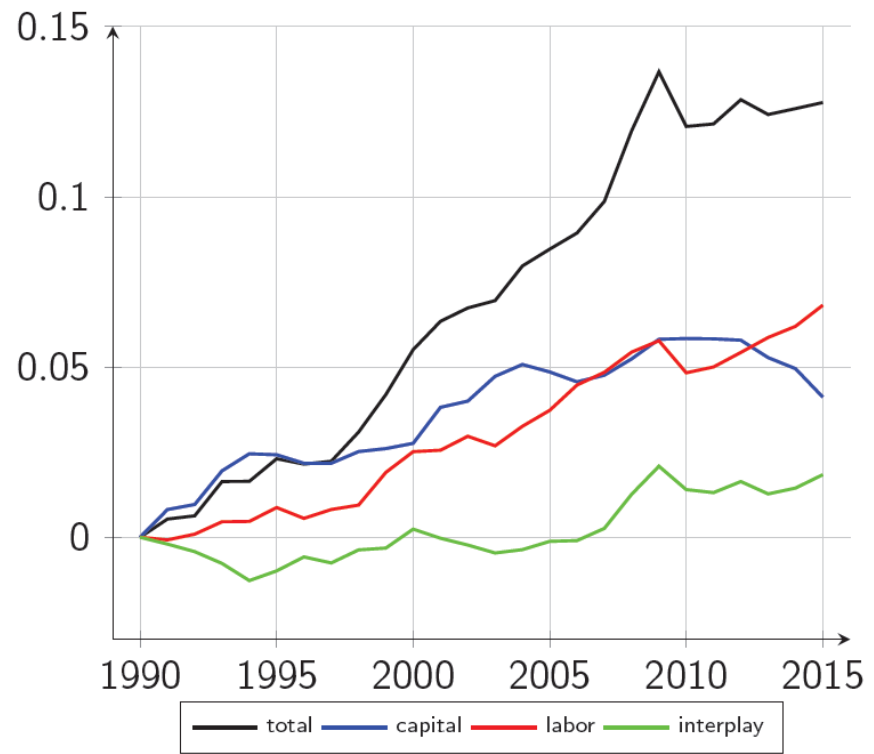

Source: author's computations using FiBEn data. All series are in logs.

The framework used to measure misallocation relies on the definition of individual production functions and output aggregators. By maximizing total output one can derive the optimal inputs allocation and the efficient level of aggregate production. Comparing with the observed aggregate output provides a measure of the loss in TFP which can be imputed to misallocation of resources. Assuming that consumers are price-takers and spend optimally the optimal allocation is such that marginal revenue products of inputs are equalized. The ratio between the observed marginal revenue products and their optimal values can therefore be seen as distortions driving the economy away from the efficient allocation. Labor (resp. capital) misallocation is thus measured as the boost in aggregate TFP one would obtain by optimally reallocating labor (resp. capital) in the absence of any capital (resp. labor) distortion. The effect of the interplay between the two kinds of misallocation is then measured as the variation in allocational efficiency that does not come from neither labor nor capital misallocation. This effect asymptotically converges to the covariance between labor and capital distortions and therefore reflects 
the fact that misallocation worsens when firms which have too much (or too few) labor also tend to have too much (or too few) capital.

This framework is applied to the French manufacturing sector using the FiBEn database. This data set covers the universe of French firms with sales at least equal to 750,000 euros. The time period goes from 1990 to 2015, therefore including the Great Recession and its aftermath. The empirical results are the following: first, allocating inputs optimally would boost aggregate TFP by almost $30 \%$ on average. The losses implied by labor and capital misallocation are found to be very similar, close to $14 \%$. The paper shows that firms suffering from a lack of labor input are also firms with relatively high nominal value added, large capital stock and high productivity. Firms that are short of capital input also tend to be highly productive, but have a relatively low nominal value added, low labor input and a dramatically small capital stock. During the decade preceding the Great Recession misallocation generates a loss in annual TFP growth of roughly 0.8 percentage points. This deterioration is mainly related to labor misallocation, except at the beginning of the 2000's, when the increase in capital misallocation is the main driver. Misallocation reaches a peak during the Great Recession and decreases in the immediate aftermath of the crisis: it accounts for 23 to 31\% of the 2007-2009 drop in aggregate TFP, and for 17 to $26 \%$ of the 2010 recovery. The striking feature of misallocation during the Great Recession is the effect of the interplay component, which is negligible the rest of the time. Mechanisms affecting both labor and capital markets may therefore be particularly important in the wake of financial crises. Finally, misallocation remains stable after 2010: the post-crisis slowdown in productivity can hardly be explained by allocational efficiency.

\title{
L'(in)efficacité de l'allocation des facteurs avant, pendant et après la Grande Récession
}

\begin{abstract}
RÉSUMÉ
Cette étude évalue l'efficacité de l'allocation des facteurs de production et son impact sur l'évolution de la productivité agrégée du secteur manufacturier en France entre 1990 et 2015. Cette efficacité est décomposée en trois parties : l'efficacité de l'allocation du facteur travail, celle du facteur capital, et l'effet de l'interaction entre ces deux allocations. L'efficacité de l'allocation des facteurs se détériore entre 1997 et 2007, générant un déficit de croissance de la productivité d'environ $0,8 \%$ par an. Cette détérioration est principalement liée au facteur travail, à l'exception du début des années 2000 où prédomine l'effet lié au facteur capital. L'inefficacité de l'allocation des facteurs joue également un rôle important pendant la Grande Récession, expliquant environ $25 \%$ du déclin de la productivité agrégée entre 2007 et 2009 et $20 \%$ du rebond observé en 2010. L'aggravation constatée pendant la crise se distingue par la prédominance de l'effet lié à l'interaction entre les facteurs travail et capital, dont l'impact est faible le reste du temps. Cela souligne l'importance des mécanismes affectant à la fois les marchés du travail et des capitaux pendant les crises financières. Enfin, l'efficacité de l'allocation des facteurs reste stable après 2010 : la productivité agrégée qui serait obtenue en cas d'allocation optimale subit donc après la crise un ralentissement encore plus marqué que celui de la productivité observée.
\end{abstract}

Mots-clés : Allocation des facteurs ; productivité agrégée ; Grande Récession

Les Documents de travail reflètent les idées personnelles de leurs auteurs et n'expriment pas nécessairement la position de la Banque de France. Ce document est disponible sur publications.banque-france.fr 


\section{Introduction}

The efficiency of inputs allocation among heterogeneous production units has recently been the subject of a vigorous interest from the economics profession. Taking advantage of the increasing availability of large micro datasets, this lively branch of the economic literature has emphasized the role of resource misallocation in accounting for differences in aggregate productivity, both across countries (Banerjee and Duflo, 2005; Restuccia and Rogerson, 2008; Hsieh and Klenow, 2009) and over time (Gopinath et al., 2017). Exploring the micro determinants of total factor productivity (TFP) is all the more relevant at a time when its evolution during and after the Great Recession is the subject of a particular concern. ${ }^{1}$

In this paper, I assess misallocation and its impact on the evolution of aggregate productivity before, during, and after the Great Recession. To do so I make use of a large dataset covering a wide sample of French firms and focus on the manufacturing sector. ${ }^{2}$ I decompose TFP into two components, one reflecting the optimal level of aggregate productivity and the other the loss in TFP due to micro distortions affecting firms inputs demands. To go further I provide an exact decomposition of the misallocation component between three distinct parts, measuring respectively the effect of labor misallocation (i.e. the gain in TFP from removing labor distortions when capital is efficiently allocated), the effect of capital misallocation (i.e. the gain in TFP from removing capital distortions when labor is efficiently allocated), and the interplay between these two sorts of distortions.

As long as consumers spend optimally, aggregate output is maximized when inputs are allocated such that firms' marginal revenue products (MRP) are equalized. As a result distortions driving these marginal revenue products away from the optimal level and creating dispersion in producers MRP also generates a loss in total production.

The ratio between the optimal level of output and the actual one is therefore an intuitive and comprehensive measure of the level of efficiency associated to the observed input allocation (Hsieh and Klenow, 2009). As aggregate inputs stocks are kept constant when comparing various allocations this measure also represents the ratio between the aggregate TFP which would be observed under an efficient allocation of resources, and the one which is observed

\footnotetext{
${ }^{1}$ See for example Fernald (2015); Reifschneider et al. (2015); Anzoategui et al. (2016).

${ }^{2}$ After data cleaning the data set consists in an unbalanced panel containing on average 38,000 firm-year observations (for a total of 100,669 distinct firms) from 1990 to 2015.
} 
under the actual allocation. Differences in aggregate TFP therefore derive from changes in efficient productivity and changes in the measure of misallocation. ${ }^{3}$

Seminal articles in the misallocation literature have focused on resource allocation as a source of measured TFP differences across countries, which itself accounts for large portion of differences in output per capita. ${ }^{4}$ Banerjee and Duflo (2005) provide evidence from the microdevelopment literature of enormous dispersion of rates of return to the same factor within a single economy. In light of these empirical facts they argue that misallocation is an important source of productivity differences across countries. Restuccia and Rogerson (2008) use a modified version of the standard growth model to make similar conclusions, showing in particular that policies creating prices heterogeneity in the supply-side of the economy can lead to sizeable decreases in output and TFP. Hsieh and Klenow (2009) (HK hereafter) use micro-data on manufacturing plants to show that hypothetically reallocating inputs to equalize marginal products to the extent observed in the US would increase TFP by 30 to $50 \%$ in China and by 40 to $60 \%$ in India. In this paper I perform a quantitative exercise inspired by the HK methodology; while they find that equalizing marginal revenue products within industries would increase US manufacturing TFP by $30.7 \%$ in 1987 and by $42.9 \%$ in 1997, I find from 1990 to 2015 an average TFP loss of $28.6 \%$ for the French manufacturing sector (22.2 in 1990, 22.9 in 1997). It suggests that while allocational efficiency could largely explain differences in TFP between developed and developing countries, there is no evidence that France may suffer from such an efficiency gap compared to the US. ${ }^{5}$

A growing strand of the literature has also explored the evolution of misallocation over time and its impact on TFP growth. In particular, recent articles have focused on the role of allocational efficiency in accounting for the relatively poor economic performance in various Southern European countries since the late 1990's (see Reis (2013); Dias et al. (2015) for Portugal, Calligaris (2015) for Italy, Garcia-Santana et al. (2016) for Spain). These articles find a significant increase in misallocation over time, implying a sizeable loss in annual output and productivity growth. Consistently with these empirical findings, I show that the French manufacturing sector experienced during the decade preceding the Great Recession a deterioration of allocational

\footnotetext{
${ }^{3}$ Importantly one has to be cautious when interpreting changes in misallocation as a decreasing or increasing scope for welfare-improving policies. As emphasized by Asker et al. (2014) allocational efficiency may reflect factors that can hardly be affected by public authorities, like physical adjustment costs.

${ }^{4}$ See Restuccia and Rogerson (2013) for a useful survey on this issue.

${ }^{5}$ See Bellone and Mallen-Pisano (2013) for a comparison of French and US allocational efficiency.
} 
efficiency, generating a loss in annual TFP growth of approximately 0.8 percentage points. One leading explanation for the productivity loss empirically observed in Southern Europe is capital misallocation induced by the fall in interest rates that followed the introduction of the euro, as emphasized by Gopinath et al. (2017). They document a significant increase in the dispersion of capital MRP, a flat dispersion of labor MRP, and a deterioration of allocational efficiency in Spain, Italy, and Portugal. ${ }^{6}$ They then show theoretically that this is the outcome of an economy where financial constraints direct capital inflows to firms that have higher net worth but are not necessarily more productive. ${ }^{7}$ Interestingly I find that misallocation in the French manufacturing sector is mainly related to a rise in capital misallocation during the few years following the creation of the euro. ${ }^{8}$ Outside this period I find that the deterioration of allocational efficiency is mainly related to an increase of labor misallocation.

This paper also contributes to the literature linking the huge drops observed in TFP during depressions with resource allocation. Decline in aggregate productivity is a notable feature of crisis episodes (Kehoe and Prescott, 2002; Calvo et al., 2006), and the Great Recession makes no exception (Christiano et al., 2015). Various articles find that inputs misallocation contributes significantly to the decrease in measured TFP during financial crises (see Oberfield (2013) for the Chilean crisis of 1982, Ziebarth (2014) for the Great Depression in the US, Sandleris and Wright (2014) for the 2001 Argentine crisis). In line with those findings, I show that between 2007 and 2009 a rise in misallocation accounts roughly for $25 \%$ of the drop in observed manufacturing TFP comparing with its pre-crisis trend. From a theoretical perspective, several recent papers have endogenized TFP as depending on financial frictions in models with heterogeneous production units (see Midrigan and Xu (2014); Moll (2014); Buera and Moll (2015) among others). In particular, credit market imperfections and their impact on capital misallocation are often seen as the main channel explaining the drop in TFP during the Great Recession (Khan and Thomas, 2013; Di Nola, 2015). To assess the relative role of capital and labor misallocation

\footnotetext{
${ }^{6}$ Surprisingly Gopinath et al. (2017) find no deterioration of allocational efficiency for France during the 2000's, including during the Great Recession.

${ }^{7}$ Challe et al. (2016) provide another explanation by linking the large capital inflows in Southern Europe following the creation of the euro currency with a significant decline in the quality of institutions. This degradation then increases the share of inefficient projects, thereby lowering average firms' TFP and increasing the dispersion of idiosyncratic productivities.

${ }^{8}$ Providing evidence on whether the mechanism described by Gopinath et al. (2017) is at work for the French manufacturing sector is beyond the scope of this paper. Cette et al. (2016) provide VAR and panel-data evidence suggesting that changes in real interest rates have influenced productivity dynamics in the second half of the 1990's and the early 2000s, in particular in Italy and Spain. They find that the decline in interest rates also had an impact on French labor productivity, although smaller.
} 
I provide in this paper an exact decomposition of HK's measure of allocational efficiency between three components, respectively reflecting the pure effect of labor misallocation, the pure effect of capital misallocation and the interplay between both kinds of misallocation. Under rather strong assumptions, namely idiosyncratic distortions and productivities are jointly lognormally distributed and the number of firms per sector is large, misallocation can be written as a weighted sum of the variances of labour and capital MRP and of the covariance between both. These moments are therefore widely used by the literature as alternative measures of allocational efficiency or as reflecting the relative strengths of labor and capital misallocation. ${ }^{9}$ The decomposition I propose, which still relies on the HK famework, has three advantages compared with the previous one. First, it does not rely on the above-mentioned assumptions. Importantly, even if one is ready to accept these assumptions, the decomposition I propose is shown to be in this case strictly equivalent to the log-normal approximation. Second, it has a more immediate economic interpretation in terms of output loss. Third, it does not ignore other important factors affecting misallocation, such as the correlation between idiosyncratic TFP and distortions on inputs MRP. ${ }^{10}$ I use this decomposition to show that the main factor behind the deterioration of allocational efficiency in the French manufacturing sector during the Great Recession is the increase of the interplay component, whereas pure capital or labor misallocation by itself can only account for a small part of the rise in misallocation. Therefore I argue that theoretical and quantitative models intending to reproduce the impact of misallocation on aggregate productivity during the crisis should be able to replicate such feature. More precisely, models where misallocation derives exclusively from distortions on capital MRP (or equivalently solely from distortions on labor MRP) may miss an important driving force.

Finally I examine the role of misallocation in shaping the post-crisis slowdown in aggregate productivity. The reduced TFP growth in the US and in Europe in the wake of the GreatRecession is a hotly debated issue. While some argue that the huge drop in economic activity experienced during the crisis damaged the productive capacity of the economy and lead to the post-crisis slowdown in TFP (Reifschneider et al., 2015; Anzoategui et al., 2016), others claim that productivity growth slowed prior to the Great Recession, ruling out causal effect of the

\footnotetext{
${ }^{9}$ See for example Larrain and Stumpner (2017).

${ }^{10}$ Restuccia and Rogerson (2008) stress that distortions that are correlated with idiosyncratic productivity considerably worsen misallocation. The fact that such correlation does not appear in the log approximation is also emphasized by Gilchrist et al. (2013).
} 
crisis itself (Fernald, 2015). Given the various empirical evidence documenting the sizeable impact of misallocation on measured productivity one may wonder to what extent this anemic growth can be a byproduct of changes in the efficiency of resource allocation. ${ }^{11}$ I show that a drop in misallocation in the immediate aftermath of the crisis can accout for roughly $20 \%$ of the 2010 recovery in observed manufacturing TFP. ${ }^{12}$ On the other hand I find that after this sharp recovery allocational efficiency remains essentially flat. As misallocation increased during the decade preceding the Great Recession, the efficient TFP growth rate was higher than the observed TFP growth rate during this period. The post-crisis slowdown in productivity growth is therefore even more pronounced for efficient TFP than for observed TFP: misallocation does not appear as a driver of TFP stagnation.

The road map for the remainder of the paper is as follows. Section 2 develops a simple theoretical framework inspired by Hsieh and Klenow (2009)'s seminal contribution. Section 3 describes the data. Section 4 presents the main empirical results regarding distortions, misallocation and its contribution to changes in observed TFP. Section 5 provides robustness checks. Section 6 concludes.

\section{Theoretical framework}

\subsection{The efficient allocation}

I consider an economy composed of $S$ distinct sectors. There are $n_{s}$ firms operating in sector $\mathrm{s}$, each firm producing a differentiated good. Individual production functions ${ }^{13}$ and aggregators at the sectoral level and at the economy level are given by :

$$
\begin{gathered}
y_{i s}=f_{i s}\left(k_{i s}, l_{i s}\right) \\
Y_{s}=F_{s}\left(y_{1 s}, \ldots, y_{n_{s} s}\right) \\
Y=F\left(Y_{1}, \ldots, Y_{S}\right)
\end{gathered}
$$

\footnotetext{
${ }^{11}$ See for example Gerth and Otsu (2016)

${ }^{12}$ Chen and Irarrazabal (2015) also study the link between misallocation and post-crisis recovery, analysing the few years following the 1982 Chilean depression.

${ }^{13}$ I follow standard models of macroeconomics and economic growth by specifying the framework directly in terms of value-added. I therefore use 2-factor production functions. For an example of how intermediate inputs and input-output tables may impact misallocation, see Jones (2013). Sandoz (2017) uses French data to introduce intermediate inputs in the standard misallocation frameworks, with a focus on international trade.
} 
Resources are optimally allocated within sector s if and only if, given the total stocks of inputs available in this sector, the distribution of capital and labor across firms is such that the maximum level of output is attained. Formally, the efficient allocation $\left\{k_{i s}^{*}, l_{i s}^{*}\right\}_{i \leq n_{s}}$ and the optimal level of sectoral production $Y_{s}^{*}$ are the solution of the following maximization program:

$$
\begin{gathered}
\max _{\left\{k_{i s}, l_{i s}\right\}_{i \leq n_{s}}} Y_{s} \\
\text { s.t } \sum_{i=1}^{n_{s}} k_{i s} \leq K_{s}, \sum_{i=1}^{n_{s}} l_{i s} \leq L_{s}
\end{gathered}
$$

First order conditions write:

$$
\begin{aligned}
& \frac{\partial F_{s}}{\partial y_{i s}}\left(y_{1 s}^{*}, \ldots, y_{n_{s} s}^{*}\right) \frac{\partial f_{i s}}{\partial k_{i s}}\left(k_{i s}^{*}, l_{i s}^{*}\right)=\frac{\partial Y_{s}^{*}}{\partial K_{s}}\left(K_{s}, L_{s}\right) \\
& \frac{\partial F_{s}}{\partial y_{i s}}\left(y_{1 s}^{*}, \ldots, y_{n_{s} s}^{*}\right) \frac{\partial f_{i s}}{\partial l_{i s}}\left(k_{i s}^{*}, l_{i s}^{*}\right)=\frac{\partial Y_{s}^{*}}{\partial L_{s}}\left(K_{s}, L_{s}\right)
\end{aligned}
$$

Assume that on the demand side a representative consumer with an exogenous revenue $R$ wants to maximize its aggregate consumption :

$$
\begin{gathered}
\max _{\left\{y_{i s}\right\}_{i \leq n_{s}, s \leq S}} Y \\
\text { s.t } \sum_{s=1}^{S} \sum_{i=1}^{n_{s}} p_{i s} y_{i s} \leq R
\end{gathered}
$$

First order conditions define total demand for each differenciated good $y_{i s}^{d}$ :

$$
\frac{\partial F}{\partial Y_{s}}\left(Y_{1}^{d}, \ldots, Y_{S}^{d}\right) \frac{\partial F_{s}}{\partial y_{i s}}\left(y_{1 s}^{d}, \ldots, y_{n_{s} s}^{d}\right)=\gamma p_{i s}
$$

where $\gamma$ is the shadow price associated with the consumer's budget constraint, and is normalized to 1 . Combining equations (4) and (5) with equation (6) and under market clearing one obtain that the efficient resource allocation is such that marginal revenue products are equalized for all firms operating in sector s :

$$
\begin{gathered}
M R P K_{i s}^{*}=M R P K_{j s}^{*} \\
M R P L_{i s}^{*}=M R P L_{j s}^{*}
\end{gathered}
$$


Let's define sectoral price as the ratio between sectoral nominal value-added and sectoral physical output :

$$
P_{s}=\frac{\sum_{i=1}^{n_{s}} p_{i s} y_{i s}}{Y_{s}}
$$

Now assume that $F_{s}$ is homogeneous of degree one. By Euler's homogeneous function theorem one gets from equation (6) the following demand equations:

$$
\begin{gathered}
\frac{\partial F}{\partial Y_{s}}\left(Y_{1}^{d}, \ldots, Y_{S}^{d}\right)=P_{s} \\
\frac{\partial F_{s}}{\partial y_{i s}}\left(y_{1 s}^{d}, \ldots, y_{n_{s} s}^{d}\right)=\frac{p_{i s}}{P_{s}}
\end{gathered}
$$

Denoting $p_{i s}^{*}$ and $P_{s}^{*}$ the equilibrium prices when the input allocation is efficient, equations (4), (5) and (8) imply that under allocational efficiency individual marginal revenue products are equal to sectoral MRP:

$$
\begin{aligned}
M R P K_{i s}^{*} & =P_{s}^{*} \frac{\partial Y_{s}^{*}}{\partial K_{s}}\left(K_{s}, L_{s}\right) \\
M R P L_{i s}^{*} & =P_{s}^{*} \frac{\partial Y_{s}^{*}}{\partial L_{s}}\left(K_{s}, L_{s}\right)
\end{aligned}
$$

It is quite standard in the literature on misallocation to map observed marginal revenue products onto exogenous distortions. Under the previous framework it is intuitive to define these distortions as wedges driving marginal revenue products away from their within-sector optimal levels. ${ }^{14}$ Formally:

$$
\begin{aligned}
& M R P K_{i s}=\left(1+\tau_{i s}^{k}\right) M R P K_{i s}^{*} \\
& M R P L_{i s}=\left(1+\tau_{i s}^{l}\right) M R P L_{i s}^{*}
\end{aligned}
$$

Using equations (7), (9) and (10) one can easily show that these two distortions write :

$$
\begin{aligned}
& 1+\tau_{i s}^{k}=\frac{\frac{k_{i s}}{y_{i s}} \frac{\partial f_{i s}\left(k_{i s}, l_{i s}\right)}{\partial k_{i}}}{\frac{K_{s}}{Y_{s}^{*}} \frac{\partial Y_{s}^{*}\left(K_{s}, L_{s}\right)}{\partial K_{s}}} \frac{\frac{Y_{s}}{Y} \frac{\partial F\left(Y_{1}, \ldots, Y_{S}\right)}{\partial Y_{s}}}{\frac{Y_{s}^{*}}{Y^{*}} \frac{\partial F\left(Y_{1}^{*}, \ldots, Y_{S}^{*}\right)}{\partial Y_{s}^{*}}} \frac{p_{i s} y_{i s}}{k_{i s}} \frac{K_{s}}{P_{s} Y_{s}} \frac{Y}{Y^{*}} \\
& 1+\tau_{i s}^{l}=\frac{\frac{l_{i s}}{y_{i s}} \frac{\partial f_{i s}\left(k_{i s}, l_{i s}\right)}{\partial l_{i s}}}{\frac{L_{s}}{Y_{s}^{*}} \frac{\partial Y_{s}^{*}\left(K_{s}, L_{s}\right)}{\partial L_{s}}} \frac{\frac{Y_{s}}{Y} \frac{\partial F\left(Y_{1}, \ldots, Y_{S}\right)}{\partial Y_{s}}}{\frac{Y_{s}^{*}}{Y^{*}} \frac{\partial F\left(Y_{1}^{*}, \ldots, Y_{S}^{*}\right)}{\partial Y_{s}^{*}}} \frac{p_{i s} y_{i s}}{l_{i s}} \frac{L_{s}}{P_{s} Y_{s}} \frac{Y}{Y^{*}}
\end{aligned}
$$

\footnotetext{
${ }^{14}$ It is important to keep in mind that these exogenous distortions can reflect a large set of frictions, like for example financial constraints, physical adjustment costs, firing costs, heterogeneous mark-ups among others.
} 


\subsection{Production functions and output aggregators}

To bring this framework to the data one requires functional-form assumptions on production functions and on output aggregation. I follow Hsieh and Klenow (2009) and use a constant return to scale production function. The output of each sector is the outcome of aggregating the differentiated goods in a CES manner. Finally, sectoral aggregates are combined into a single aggregate good using a Cobb-Douglas production technology.

$$
\begin{gathered}
y_{i s}=z_{i s} k_{i s}^{\alpha_{s}} l_{i s}^{1-\alpha_{s}} \\
Y_{s}=\left(\sum_{i=1}^{n_{s}} y_{i s}^{\frac{\rho_{s}-1}{\rho_{s}}}\right)^{\frac{\rho_{s}}{\rho_{s}-1}} \\
Y=\prod_{s=1}^{S} Y_{s}^{\theta_{s}} \text { where } \sum_{s=1}^{S} \theta_{s}=1
\end{gathered}
$$

$z_{i s}$ is the idiosyncratic productivity of firm i in sector s. ${ }^{15} \rho_{s}$ is the elasticity of substitution between goods within sector s. Notice that output elasticities are allowed to differ across industries but not across firms within a given industry.

Under the previous functional-form assumptions demand equations (7) and (8) write:

$$
\begin{gathered}
\frac{P_{s} Y_{s}}{Y}=\theta_{s} \\
\frac{y_{i s}}{Y_{s}}=\left(\frac{p_{i s}}{P_{s}}\right)^{-\rho_{s}}
\end{gathered}
$$

I follow Foster et al. (2008) by distinguishing between revenue productivity (TFPR) and physical productivity (TFPQ) :

$$
\begin{gathered}
T F P R_{i s}=p_{i s} z_{i s}=\frac{p_{i s} y_{i s}}{k_{i s}^{\alpha_{s}} l_{i s}^{1-\alpha_{s}}} \\
T F P Q_{i s}=z_{i s}=\frac{y_{i s}}{k_{i s}^{\alpha_{s}} l_{i s}^{1-\alpha_{s}}}
\end{gathered}
$$

In most firm-level datasets variables are expressed in nominal terms and firm-specific prices are

\footnotetext{
${ }^{15}$ Here idiosyncratic productivity is considered as exogenous. See Syverson (2011) for a survey on the determinants of micro-productivity.
} 
not available, which makes revenue productivity easier to measure than physical productivity. ${ }^{16}$ Using demand equations one can derive physical productivity from nominal value-added and inputs quantities:

$$
T F P Q_{i s}=\left(Y_{s} P_{s}^{\rho_{s}}\right)^{-\frac{1}{\rho_{s}-1}} \frac{\left(p_{i s} y_{i s}\right)^{\frac{\rho_{s}}{\rho_{s}-1}}}{k_{i s}^{\alpha_{s}} l_{i s}^{1-\alpha_{s}}}
$$

Interestingly, the previous equation implies that in a given sector and at a given time period one can obtain relative idiosyncratic productivities without using sectoral deflators (and therefore avoiding a potential source of measurement error, since the use of sectoral deflators would mean that differences in firm-specific prices would show up in the measure of physical productivities).

\subsection{Capital, labor and the log-normality assumption}

The previous assumptions on production functions and sectoral aggregators imply that the capital (labor) elasticity of individual output in sector $\mathrm{s}$ is equal to the capital (labor) elasticity of the sectoral production function one obtain under optimal allocation. The Cobb-Douglas aggregator implies that the sectoral output elasticity of aggregate production is a constant. Therefore from equations (11) and (12) labor distortions and capital distortions write:

$$
\begin{aligned}
& 1+\tau_{i s}^{k}=\frac{p_{i s} y_{i s}}{k_{i s}} \frac{K_{s}}{P_{s} Y_{s}} \frac{Y}{Y^{*}} \\
& 1+\tau_{i s}^{l}=\frac{p_{i s} y_{i s}}{l_{i s}} \frac{L_{s}}{P_{s} Y_{s}} \frac{Y}{Y^{*}}
\end{aligned}
$$

One can express observed aggregate TFP at the sectoral level as a function of idiosyncratic productivities and capital and labor distortions:

$$
\begin{gathered}
\text { TFP } P_{s}=\frac{Y_{s}}{K_{s}^{\alpha_{s}} L_{s}^{1-\alpha_{s}}} \\
=\frac{\left(\sum_{i=1}^{n_{s}} z_{i s}^{\rho_{s}-1}\left(1+\tau_{i s}^{k}\right)^{\left(1-\rho_{s}\right) \alpha_{s}}\left(1+\tau_{i s}^{l}\right)^{\left(1-\rho_{s}\right)\left(1-\alpha_{s}\right)}\right)^{\frac{\rho_{s}}{\rho_{s}-1}}}{\left(\sum_{i=1}^{n_{s}} z_{i s}^{\rho_{s}-1}\left(1+\tau_{i s}^{k}\right)\left(1-\rho_{s}\right) \alpha_{s}-1\left(1+\tau_{i s}^{l}\right)^{\left(1-\rho_{s}\right)\left(1-\alpha_{s}\right)}\right)^{\alpha_{s}}\left(\sum_{i=1}^{n_{s}} z_{i s}^{\rho_{s}-1}\left(1+\tau_{i s}^{k}\right)^{\left(1-\rho_{s}\right) \alpha_{s}}\left(1+\tau_{i s}^{l}\right)^{\left(1-\rho_{s}\right)\left(1-\alpha_{s}\right)-1}\right)^{1-\alpha_{s}}}
\end{gathered}
$$

From equation (21) one can easily get the efficient sectoral productivity $T F P_{s}^{*}$ by equalizing

\footnotetext{
${ }^{16}$ Furthermore, under constant return to scale the equalization of inputs MRP implies the equalization of firms' TFPR.
} 
inputs MRP (that is to say, by setting distortions equal to 1). Interestingly one can also get the TFP that would have been observed if, for an unchanged distribution of MRPK (MRPL), labor (capital) had been efficiently allocated, i.e. MRPL (MRPK) had been equalized. This variable is denoted $T F P_{s}^{*, l}\left(T F P_{s}^{*, k}\right)$. Following Hsieh and Klenow (2009), an intuitive measure of the extent of misallocation in sector $\mathrm{s}$ is given by the ratio between efficient TFP and observed TFP, assessing the loss in sectoral productivity (or equivalently in output) associated with the current inputs allocation. I use the same intuition and define capital misallocation (labor misallocation) as the ratio between $T F P_{s}^{*}$ and $T F P_{s}^{*, l}\left(T F P_{s}^{*, k}\right)$, assessing the loss in TFP induced by distortions affecting the MRPK (MRPL) distribution. In other words, this measure of capital (labor) misallocation provides an answer to the following question: if there were no labor (capital) distortions in sector s, by how much could we still boost sectoral TFP eliminating capital (labor) distortions? Formally these three measures write :

$$
\begin{aligned}
M_{s} & =\frac{T F P_{s}^{*}}{T F P_{s}} \\
M_{s, k} & =\frac{T F P_{s}^{*}}{T F P_{s}^{*, l}} \\
M_{s, l} & =\frac{T F P_{s}^{*}}{T F P_{s}^{*, k}}
\end{aligned}
$$

$M_{s, k}$ and $M_{s, l}$ measure respectively the extent of capital and labor misallocation in sector $\mathrm{s}$, making use of the theoretical framework previously defined. To disentangle these two types of misallocation the literature has widely used reduced-form estimates, in particular looking at measures of MRP dispersion. ${ }^{17}$ Indeed, under the assumption that idiosyncratic productivity, capital distortion and labor distortion are jointly log-normal within each sector one can show that (see Appendix A):

$$
\ln \left(M_{s}\right) \underset{n_{s} \rightarrow \infty}{\stackrel{a . s .}{\longrightarrow}} \frac{1}{2} \alpha_{s}\left(1+\alpha_{s}\left(\rho_{s}-1\right)\right) \operatorname{Var}\left[\ln \left(1+\tau_{s}^{k}\right)\right]
$$

\footnotetext{
${ }^{17}$ Gopinath et al. (2017) compare the evolution of MRPK dispersion and MRPL dispersion over time in various southern-european countries. They find that MRPL dispersion is stable while MRPK dispersion increases, which motivates the use of a model linking capital misallocation with the decline of the real interest rate following the introduction of the euro. Larrain and Stumpner (2017) show that capital account liberalization reduces the dispersion in the return to capital, particularly in sectors more reliant on external finance. They map this reduction into aggregate TFP gains, and argue that capital account liberalization increases aggregate TFP through more efficient firm capital allocation by $10 \%$ to $16 \%$.
} 


$$
\begin{aligned}
& +\frac{1}{2}\left(1-\alpha_{s}\right)\left(1+\left(1-\alpha_{s}\right)\left(\rho_{s}-1\right)\right) \operatorname{Var}\left[\ln \left(1+\tau_{s}^{l}\right)\right] \\
& +\alpha_{s}\left(1-\alpha_{s}\right)\left(\rho_{s}-1\right) \operatorname{Cov}\left[\ln \left(1+\tau_{s}^{k}\right), \ln \left(1+\tau_{s}^{l}\right)\right]
\end{aligned}
$$

Under this approximation misallocation can come from either dispersion in log-MRPK, dispersion in $\log$-MRPL, or correlation between the two distortions. If labor distortions are equalized the variance of $\log$-MRPK is the only source of misallocation, and therefore constitutes a sufficient statistic to measure "pure" capital misallocation. Although very useful, this approximation may seem unsatisfying for several reasons. First, it necessitates additional assumptions with respect to the HK framework (the log-normality assumption, and the fact that the number of firms per sector need to be large). More importantly, the correlation between idiosyncratic productivities and distortions does not appear in this decomposition, whereas misallocation is worse when firms that suffer from a lack of resources (i.e., firms with high MRP) are also the most productive ones. ${ }^{18}$ The measures of capital and labor misallocation I propose stick to the structural framework without any further assumptions, and do not ignore the above-mentioned correlation.

I define a third term, representing the impact of the interaction between labor and capital distortions, such that the log of sectoral misallocation is equal to the sum of the log of each component:

$$
\ln \left(M_{s}\right)=\ln \left(M_{s, k}\right)+\ln \left(M_{s, l}\right)+\ln \left(M_{s, i n t}\right)
$$

It can be shown (Appendix A) that under the log-normality assumption each part of equation (26) is directly related to its counterpart in equation (25):

$$
\begin{gathered}
\ln \left(M_{s, k}\right) \underset{n_{s} \rightarrow \infty}{\stackrel{a . s .}{\longrightarrow}} \frac{1}{2} \alpha_{s}\left(1+\alpha_{s}\left(\rho_{s}-1\right)\right) \operatorname{Var}\left[\ln \left(1+\tau_{s}^{k}\right)\right] \\
\ln \left(M_{s, l}\right) \underset{n_{s} \rightarrow \infty}{\stackrel{a . s .}{\longrightarrow}} \frac{1}{2}\left(1-\alpha_{s}\right)\left(1+\left(1-\alpha_{s}\right)\left(\rho_{s}-1\right)\right) \operatorname{Var}\left[\ln \left(1+\tau_{s}^{l}\right)\right] \\
\ln \left(M_{s, \text { int }}\right) \underset{n_{s} \rightarrow \infty}{\stackrel{a . s .}{\longrightarrow}} \alpha_{s}\left(1-\alpha_{s}\right)\left(\rho_{s}-1\right) \operatorname{Cov}\left[\ln \left(1+\tau_{s}^{k}\right), \ln \left(1+\tau_{s}^{l}\right)\right]
\end{gathered}
$$

Therefore, and importantly, even if one is ready to consider as plausible the assumptions needed to get equation (25), and to overlook the fact that it ignores important factors affecting

\footnotetext{
${ }^{18}$ See Restuccia and Rogerson (2008) and Gilchrist et al. (2013).
} 
misallocation, the decomposition I propose would be in this case strictly equivalent to the lognormal approximation.

\subsection{Misallocation and aggregate TFP}

Aggregate TFP is given by:

$$
T F P=\prod_{s=1}^{S}\left(T F P_{s}\left(\frac{K_{s}}{K}\right)^{\alpha_{s}}\left(\frac{L_{s}}{L}\right)^{1-\alpha_{s}}\right)^{\theta_{s}}
$$

and aggregate misallocation is a simple function of sectoral misallocations :

$$
M=\frac{T F P^{*}}{T F P}=\prod_{s=1}^{S} M_{s}^{\theta_{s}}
$$

Therefore variation in observed aggregate TFP over time can be decomposed into variations in efficient TFP and variations in misallocation:

$$
\Delta \ln (T F P)=\Delta \ln \left(T F P^{*}\right)-\Delta \ln (M)
$$

Variation in aggregate misallocation can itself be decomposed using equation (26) into three components: capital misallocation, labor misallocation and the interaction term.

$$
\begin{gathered}
\Delta \ln (M)=\Delta \ln \left(M_{k}\right)+\Delta \ln \left(M_{l}\right)+\Delta \ln \left(M_{\text {int }}\right) \\
\ln \left(M_{k}\right)=\sum_{s=1}^{S} \theta_{s} \ln \left(M_{s, k}\right) \\
\ln \left(M_{l}\right)=\sum_{s=1}^{S} \theta_{s} \ln \left(M_{s, l}\right) \\
\ln \left(M_{\text {int }}\right)=\sum_{s=1}^{S} \theta_{s} \ln \left(M_{s, \text { int }}\right)
\end{gathered}
$$




\section{Data}

\subsection{Data description}

In this section I describe the firm-level dataset I use to perform my analysis, the FIBEN database. This unique database was initially set up by the Banque de France to facilitate the implementation of monetary policy. All the companies recorded in the database are awarded a rating that provides information on their ability to meet their financial commitments. Only claims on the most highly-rated companies are eligible for bank refinancing.

The database gathers information on all companies with sales at least equal to 750,000 euros, covering the years 1989 to the present day. A broad range of information is gathered, including accounting and financial data from balance sheets and profit and loss statements, but also descriptive details, such as the firm's name, legal status and business code. The information is gathered from a variety of sources, including journals of legal notices, registrars of commercial courts, France's national statistics office (INSEE) and credit institutions, as well as the companies themselves.

I drop from the dataset observations for which the basic accounting equality does not hold. When the average number of employees declared by the firm is equal to zero I set this variable as missing. Restricting the database to the manufacturing sector the dataset is an unbalanced panel of approximately 1,100,000 observations covering a total of about 110,000 firms. Table 1 provides descriptive statistics for some variables of interest, including nominal value added (given by the difference between gross output and intermediate consumptions), payments to labor, tangible and intangible fixed assets, and average number of employees.

Table 1: Descriptive statistics, French manufacturing sector

\begin{tabular}{cccccccc}
\hline \hline Variable & Obs. & Firms & Mean & SD & Q1 & Median & Q3 \\
\hline No. employees & $1,043,427$ & 107,124 & 76.27 & 564.42 & 11 & 21 & 46 \\
Sales & $1,076,460$ & 110,124 & $19,403.92$ & $347,409.6$ & 1,268 & 2,472 & 6,478 \\
Nominal VA & $1,076,460$ & 110,124 & $4,885.22$ & $62,966.17$ & 490 & 901 & 2,065 \\
Fixed assets & $1,075,161$ & 110,108 & $3,074.36$ & $44,828.07$ & 92 & 253 & 777 \\
Total assets & $1,074,939$ & 110,104 & $15,304.6$ & $224,845.3$ & 738 & 1,532 & 4,247 \\
Wage bill & $1,075,155$ & 110,108 & $2,145.21$ & $19,190.58$ & 275 & 500 & 1,089 \\
Age & $1,061,644$ & 106,294 & 293.1 & 262.5 & 120 & 220 & 379.5 \\
\hline \hline
\end{tabular}

Note : Nominal value added is given by the difference between gross nominal output and intermediate consumptions. Age is expressed in months. All other variables except the number of employees are expressed in thousands of euros. 
The first challenge in the dataset is to harmonize accounting periods; as a matter of fact, even if most of the firms follow the regular calendar year, a non-negligible share of the data collected corresponds to other accounting periods. In order to deal with this issue I assume that the gross output, the intermediate consumption, the payments to labor and the number of employees of a given firm over a given accounting period are the same each month. Then for each firm I reconstruct yearly data by summing monthly data (or averaging, in the case of the number of employees). In the dataset the stock of fixed assets is recorded at the end of the accounting period; I proceed with linear interpolation to estimate the quantity of assets at the end of the calendar year, and I assume that fixed assets used by a firm in order to produce during year $t$ correspond to the mean of the fixed assets stocks at the end of year t-1 and year t. ${ }^{19}$

I use INSEE's aggregate data (publicly available online) to check for the representativeness of my sample. More precisely I use the sectoral time series of nominal value-added, wages and salaries and employment (excluding self-employment), and compare it to their counterparts in the dataset. I first notice that within the manufacturing sector the relative size of the manufacture of coke and refined petroleum products is highly overestimated. As a matter of fact, this sector represents on average $6.4 \%$ of total manufacturing value-added in my data, while its average share in the French manufacturing sector between 1990 and 2015 is close to $0.8 \%$. Because this overestimation would distort my empirical results I remove this industry from the dataset, dropping 1466 firm-year observations in the process. I also notice that the representativeness of the manufacturing sector is way better than for the other sectors of the economy : the dataset accounts on average for $91.6 \%$ of manufacturing value-added, $95 \%$ of wages and salaries and $92.7 \%$ of employment ${ }^{20}$ (see Table 2). In comparison the dataset covers in average $50.9 \%$ of total nominal value-added in services ${ }^{21}$ ( $53.9 \%$ for wages, $52.9 \%$ for employment), $45.8 \%$ in the construction sector (50.9\% for wages, $57.2 \%$ for employment) and $10.1 \%$ in the agricultural sector (29\% for wages, $17.9 \%$ for employment). Therefore I focus in the rest of the paper on the manufacturing industry, in line with numerous articles in the misallocation literature.

Throughout my analysis I assume that industries in my framework correspond to three-

\footnotetext{
${ }^{19}$ Because I use the lag value of fixed assets in order to define the capital stock variable I drop the first year of observations in my dataset, which therefore goes from 1990 to 2015.

${ }^{20}$ As I do not control for employees who work in multiple jobs the representativeness in terms of employment may be slightly overestimated. However this remark does not apply to wages or value-added.

${ }^{21}$ Excluding financial and real estate activities.
} 
Table 2: Coverage (in \%) in FIBEN relative to INSEE, French manufacturing sector

\begin{tabular}{cccc}
\hline \hline Year & Employment & Wage Bill & Nominal VA \\
\hline 1990 & 92.1 & 95.9 & 95.3 \\
1995 & 92.9 & 96.1 & 96 \\
2000 & 94.1 & 96.3 & 93.3 \\
2005 & 92.5 & 92.2 & 92.1 \\
2010 & 93.9 & 93.9 & 90.9 \\
2015 & 91.9 & 94.4 & 88 \\
Average & 92.7 & 95 & 91.6 \\
\hline \hline
\end{tabular}

Note : The manufacture of coke and refined petroleum products is excluded.

digit industries in the dataset. ${ }^{22}$ I measure labor input at the firm level as the average number of employees multiplied by the average number of hours worked by employee over the year in the corresponding sector. ${ }^{23}$ I measure the capital stock with the book value of tangible and intangible fixed assets, net of depreciation, deflated by the industry price deflator for investment goods. Finally, I measure production with nominal value added (gross output minus intermediate consumption) deflated by the corresponding value-added deflator. ${ }^{24}$ Firm-level observations are dropped if the capital stock, the labor input or the value-added variable are either non-positive or missing. At this point the dataset is composed of 976,451 firm-year observations.

Importantly, entry and exit from the dataset do not correspond to actual entry and exit; firms may disappear from the dataset when their sales fall below the 750,000 euros threshold, and exit may also reflect restructurations and takeovers rather than firms shutting down their businesses. Finally, I emphasize that I work only with unconsolidated accounts.

\subsection{Estimation of the parameters}

I now describe how I infer the parameters used in the theoretical framework from the dataset. In a perfect economy with no frictions one would naturally approximate the elasticity of output with respect to labor by the share of nominal value-added devoted to nominal expenditure on

\footnotetext{
${ }^{22}$ The FIBEN database use the NACE classification (European standard classification of productive economic activities).

${ }^{23}$ In some studies labor input is measured by the wage bill. The main assumption is that wages per worker enable to adjust the measure of idiosyncratic productivities to firm differences in hours worked per worker and in workers skills. However differences in wages may also be explained by rent sharing and by wage bargaining between the firms and the workers. I will use this alternative specification as a robustness check.

${ }^{24}$ The average number of hours worked by employee for a given year, the investment deflators and the valueadded deflators are taken from the INSEE database (available online), although the data are given for a broader level of aggregation than the three-digit level.
} 
labor. But as the whole analysis relies on the existence of distortions driving the economy away from an efficient optimum one cannot separately identify differences in technology and differences in distortions from differences in factor expenditure shares. I assume that on average firms within a given industry are undistorted (even if a particular firm still may face a distortion in a particular year). More precisely, I compute for each year and for each firm operating in industry s its labor expenditure share ${ }^{25}$ and I assume that the median of this variable over the years and over the firms reflects the true value of the elasticity of output with respect to labor. Then under the assumption of constant return to scale it is straightforward to deduce for each industry the elasticity of output with respect to capital. ${ }^{26}$ As stressed by Hsieh and Klenow (2009) another issue that arises when deducing production elasticities from factor shares is that we have to take into account the markups associated with the market power of the firms in these differentiated good industries. I assume that rents coming from these markups are divided between workers and capital owners proportionally to the factor expenditure shares, and directly appear in the payments to labor used to deduce output elasticities.

In order to measure sectors' shares $\theta_{s}$ I compute for each year and for each sector the ratio of the sectoral nominal value added to total nominal value added in the economy. These parameters are time-varying.

Most empirical studies in the misallocation literature set the elasticity of substitution between goods $\rho_{s}$ equal to an arbitrary value, considered as the same for all sectors in the economy. In line with these studies I set $\rho_{s}$ equal to 3 in my baseline computations. However this assumption may seem unsatisfying, as the value of the elasticity of substitution is bound to vary across sectors and probably impacts the magnitude of the results. As a matter of fact, it determines the sectoral aggregates (equation (14)), the elasticity of the individual demand equations (equation (17)) and the measures of idiosyncratic productivity (equation (18)). Allowing elasticities to vary across sectors constitutes therefore an important step forward. As a robustness check I estimate sector specific elasticities, using an econometric strategy inspired by De Loecker (2011)

\footnotetext{
${ }^{25}$ Payments to labor used to compute labor expenditure shares include the wage bills, fringe benefits and employer social security contributions.

${ }^{26}$ I do not use standard semi-parametric methods such as Olley and Pakes (1996) and Levinsohn and Petrin (2003) for two reasons. First these methods require assumptions on firms capital and labor demands, whereas one advantage of the structural framework I develop is that it does not require any hypothesis on how firms behave. Second, these methods frequently provide very low elasticities for capital, because this input is notoriously more prone to measurement errors than labor.
} 
(see Appendix B). ${ }^{27}$

\section{Empirical results}

I now apply the theoretical framework developed in section 2 to the FIBEN dataset in order to quantify the evolution of misallocation over time and its contribution to the variation in observed TFP.

To guard against the effect of mismeasurement I follow Hsieh and Klenow (2009) and trim the top and bottom $1 \%$ outliers of both physical and revenue productivity for each year and within each sector. After trimming the dataset includes 945,014 firm-year observations.

\section{1 distortions and firm characteristics}

Tables 3 and 4 respectively present univariate comparisons of key descriptive variables by labor distortion and capital distortion quartiles. The quartiles are constructed each year and for each sector. All variables except log distortions are normalized by their sector-year means. I am interested in whether the characteristics of firms which suffer from a lack of resources (i.e., firms with high labor or capital distortions) differ from those which should be granted less inputs (i.e., firms with low labor or capital distortions).

Firms' value added and capital stock increase monotonically with labor distortions. It suggests that for a given distribution of capital labor should optimally be reallocated from firms with relatively low nominal VA and capital stock to firms with relatively high nominal VA and capital stock: the mean firm in the fourth quartile produces $41 \%$ more and owns a capital stock $52 \%$ higher than its sector-year average, while the mean firm in the first quartile produces $43 \%$ less and owns $44 \%$ less capital. As for labor input itself the pattern is not so clear: the mean increases until Q3 but then decreases for the fourth quartile, while the labor input of the median firm is decreasing with labor distortions. The same observation applies to the age variable, both the mean and the median increasing until Q3 and then decreasing for the fourth quartile.

Regarding capital distortions, the mean of value-added, labor and capital decreases monotonically (although the median for value-added and labor in Q1 is lower than in Q2). It suggests

\footnotetext{
${ }^{27}$ I do not claim that this econometric strategy enables me to control for all sources of endogeneity bias. Moreover it relies on arguably strong (although standard) assumptions. The main point here is to get reasonable estimates and to check if my main empirical results still hold when allowing for sector specific elasticities.
} 
that for a given distribution of labor one can increase output by reallocating capital from firms with high nominal VA, high labor input and high capital stock to firms producing less with less inputs. The results for the capital variable are particularly striking: the capital stock of the mean firm in Q1 is 2.5 times larger than the sector-year average, while the mean firm in Q4 owns a capital stock more than 7 times smaller. Considering the age variable, it is again hard to draw any firm conclusion, both mean and median increasing then decreasing with capital distortions.

Tables 3 and 4 also provide useful information on the dispersion of both MRP distributions, and on the correlation with firms' productivity. On one hand substracting the median log-distortion in Q1 from the median log-distortion in Q4 indicates that the MRPK dispersion is higher than the MRPL dispersion (2.094 versus 0.809 for the difference between median logdistortions, 2.354 versus 0.946 for the difference between mean log-distortions). It suggests that there is relatively more room for capital reallocation than for labor reallocation if one wants to improve allocational efficiency. On the other hand TFPQ increases monotonically with both distortions, meaning that firms suffering from a lack of resources are also the most productive ones. However, the productivity gap between low MRPL and high MRPL firms is more pronounced: the mean firm in the fourth (first) labor distortion quartile is $59.8 \%$ more (46\% less) productive than its sector-year average, while the mean firm in the fourth (first) capital distortion quartile is only $9.7 \%$ more $(10.8 \%$ less $)$ productive. Other things equal, this bigger productivity gap would make labor misallocation relatively worse than capital misallocation.

Finally, one can also notice in both tables that labor distortion slightly decrease with capital distortion. It suggests that firms which would be granted relatively more labor input (for a given capital allocation) would also be granted relatively less capital input (for a given labor allocation).

\subsection{Misallocation and contribution to the variations in TFP}

Table 5 presents the magnitude of capital, labor and total misallocation as defined in section 2. First it is interesting to notice that the mean TFP losses one can attribute respectively to labor and capital distortions are very similar: in both cases, equalizing marginal revenue products when there are no distortions for the other input would boost aggregate TFP by 
Table 3: Firm characteristics by labor distortion quartiles

\begin{tabular}{ccccc}
\hline \hline Variable & First quartile & Second quartile & Third quartile & Fourth quartile \\
\hline \multirow{2}{*}{ Value added } & 0.570 & 0.862 & 1.164 & 1.407 \\
& $(0.322)$ & $(0.435)$ & $(0.510)$ & $(0.592)$ \\
Labor & 0.902 & 1.022 & 1.121 & 0.955 \\
& $(0.518)$ & $(0.517)$ & $(0.489)$ & $(0.389)$ \\
Capital & 0.554 & 0.783 & 1.144 & 1.521 \\
& $(0.182)$ & $(0.256)$ & $(0.320)$ & $(0.375)$ \\
TFPQ & 0.540 & 0.804 & 1.062 & 1.598 \\
& $(0.466)$ & $(0.681)$ & $(0.867)$ & $(1.253)$ \\
Age & 0.936 & 1.018 & 1.045 & 1.000 \\
& $(0.723)$ & $(0.801)$ & $(0.829)$ & $(0.796)$ \\
$\ln \left(1+\tau_{i s}^{k}\right)$ & 0.358 & 0.355 & 0.304 & 0.288 \\
& $(0.295)$ & $(0.285)$ & $(0.233)$ & $(0.227)$ \\
$\ln \left(1+\tau_{i s}^{l}\right)$ & -0.763 & -0.440 & -0.215 & 0.183 \\
\hline \hline
\end{tabular}

Note: Univariate comparison of means and medians of measures of firm characteristics. Quartiles are constructed each year and for each sector. All variables except log distortions are normalized by their sector-year means. Median values are bracketed.

Table 4: Firm characteristics by capital distortion quartiles

\begin{tabular}{ccccc}
\hline \hline Variable & First quartile & Second quartile & Third quartile & Fourth quartile \\
\hline \multirow{2}{*}{ Value added } & 1.310 & 1.153 & 0.898 & 0.638 \\
& $(0.488)$ & $(0.504)$ & $(0.451)$ & $(0.372)$ \\
Labor & 1.280 & 1.148 & 0.910 & 0.660 \\
& $(0.522)$ & $(0.544)$ & $(0.486)$ & $(0.399)$ \\
Capital & 2.475 & 0.944 & 0.435 & 0.139 \\
& $(0.848)$ & $(0.406)$ & $(0.206)$ & $(0.066)$ \\
TFPQ & 0.892 & 0.999 & 1.013 & 1.097 \\
& $(0.626)$ & $(0.737)$ & $(0.783)$ & $(0.881)$ \\
Age & 0.983 & 1.047 & 1.022 & 0.948 \\
& $(0.756)$ & $(0.827)$ & $(0.813)$ & $(0.752)$ \\
$\ln \left(1+\tau_{i s}^{k}\right)$ & -0.800 & -0.007 & 0.565 & 1.554 \\
& $(-0.705)$ & $(-0.014)$ & $(0.543)$ & $(1.389)$ \\
$\ln \left(1+\tau_{i s}^{l}\right)$ & -0.297 & -0.307 & -0.317 & -0.319 \\
\hline \hline
\end{tabular}

Note: Univariate comparison of means and medians of measures of firm characteristics. Quartiles are constructed each year and for each sector. All variables except log distortions are normalized by their sector-year means. Median values are bracketed.

$14.1 \%$ on average. As for total misallocation, I find that the mean TFP gap between the efficient inputs allocation and the observed one is equal to $28.6 \%$. My results are comparable to those in Bellone and Mallen-Pisano (2013) (who also use french data on the manufacturing sector): the TFP loss I estimate is equal to $24.3 \%$ in 1998, 30\% in 2001 and $30.7 \%$ in 2005, while they find a TFP gap of respectively $30.5 \%, 27.5 \%$ and $30.5 \%$. 
Furthermore, table 5 shows that misallocation seems to worsen over time. Capital misallocation is minimal in 1990, and culminates in 2012; labor misallocation reaches its minimum in 1991 and 1992, and is maximal in 2015; total misallocation is minimal in 1991, and reaches a peak in 2008. However, because firms appear in the dataset only when their sales exceed 750,000 euros, entry and exit between two consecutive years reflect this threshold effect and not necessarily firms shutting down their businesses. These artificial entry and exit make it hard to properly assess the evolution of misallocation over time, and its impact on productivity.

Table 5: capital misallocation, labor misallocation and total misallocation by year

\begin{tabular}{cccc}
\hline \hline & Capital misallocation & Labor misallocation & Total misallocation \\
\hline 1990 & 1.104 & 1.124 & 1.222 \\
1991 & 1.107 & 1.116 & 1.217 \\
1992 & 1.127 & 1.116 & 1.223 \\
1993 & 1.120 & 1.124 & 1.234 \\
1994 & 1.117 & 1.124 & 1.230 \\
1995 & 1.115 & 1.127 & 1.234 \\
1996 & 1.120 & 1.118 & 1.230 \\
1997 & 1.116 & 1.120 & 1.229 \\
1998 & 1.119 & 1.122 & 1.243 \\
1999 & 1.126 & 1.130 & 1.254 \\
2000 & 1.122 & 1.143 & 1.270 \\
2001 & 1.137 & 1.150 & 1.300 \\
2002 & 1.142 & 1.147 & 1.289 \\
2003 & 1.161 & 1.135 & 1.296 \\
2004 & 1.155 & 1.137 & 1.285 \\
2005 & 1.159 & 1.144 & 1.307 \\
2006 & 1.164 & 1.153 & 1.315 \\
2007 & 1.155 & 1.157 & 1.324 \\
2008 & 1.165 & 1.171 & 1.358 \\
2009 & 1.160 & 1.163 & 1.355 \\
2010 & 1.163 & 1.149 & 1.337 \\
2011 & 1.157 & 1.155 & 1.332 \\
2012 & 1.167 & 1.156 & 1.344 \\
2013 & 1.161 & 1.158 & 1.334 \\
2014 & 1.161 & 1.157 & 1.330 \\
2015 & 1.154 & 1.173 & 1.345 \\
Average & 1.141 & 1.141 & 1.286 \\
\hline
\end{tabular}

Note: This table presents for each year the aggregate TFP (or equivalently aggregate output) loss due to allocational inefficiency. Total misallocation is the ratio between efficient TFP (i.e, the level of aggregate productivity one would obtain if inputs were optimally allocated within sectors) and observed TFP. Capital misallocation is the ratio between efficient TFP and the level of TFP one would obtain if, keeping unchanged capital distortions, labor was optimally allocated. Labor misallocation is the ratio between efficient TFP and the level of TFP one would obtain if, keeping unchanged labor distortions, capital was optimally allocated.

In order to cope with this issue I make use of additional data available at the banque de 
France, keeping track of the main judicial or administrative stages in the life of the firms, and gathered from registrars of commercial courts, journals of legal notices, or from the companies themselves. I focus on events associated with entry (first registration at the register of commerce) and exit (cessation of activity, judicial liquidation). To evaluate the change in misallocation between year $t$ and year $t+1$ I consider the set of firms appearing either at $t, t+1$, or both; I drop from the sample firms which disappear in year $t+1$ but for which I have no event associated with exit at this date, and firms which appear in year $t+1$ but for which $\mathrm{I}$ have no event associated with entry at this date. Using this procedure I may drop from the sample firms which really stop their activities or which really start a business, but do not report it to legal institutions, and for which I have therefore no information. Thus I cannot claim that I do not drop any actual entry or exit; but I make sure that I drop every artificial ones. Then I compute the variation (in $\log$ ) of misallocation and of its three components between $t$ and $t+1$. Finally I assess the evolution of misallocation over time by summing the variations for all consecutive years.

Figure 1: Variation of misallocation over time

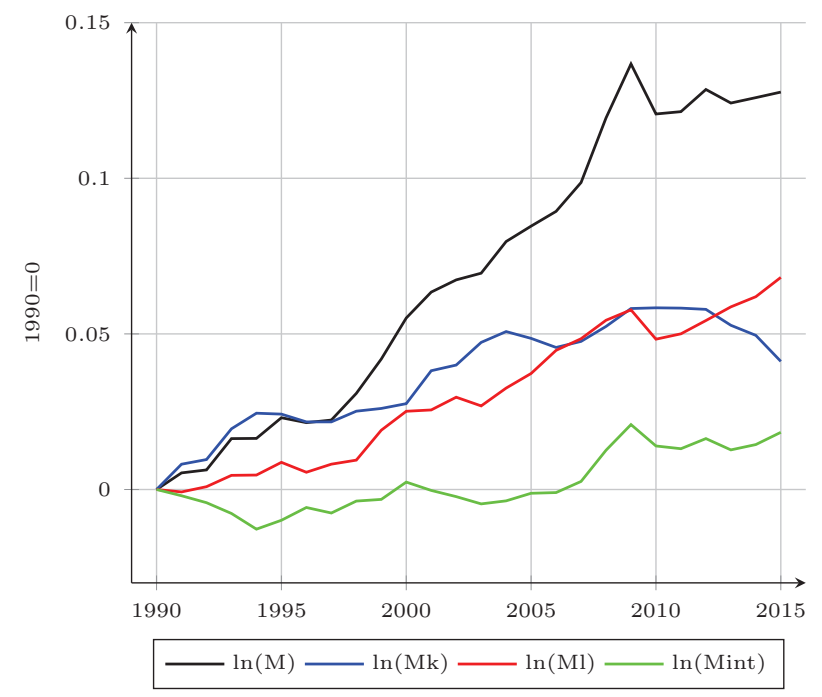

Note: This figure presents variations of aggregate misallocation and its three components over time in the French manufacturing sector. All series are in logs with 1990 normalized to 0.

Figure 1 and table 6 present the evolution of total misallocation and of its three components: labor misallocation, capital misallocation, and the interplay between both types of distortions. Aggregate misallocation follows an increasing trend over time, especially during the decade preceding the Great Recession. From 1997 to 2007, the annual TFP growth was in average 0.76 
Table 6: Changes in total misallocation and in its three components

\begin{tabular}{lcccc}
\hline \hline & $\Delta M$ & $\Delta M_{k}$ & $\Delta M_{l}$ & $\Delta M_{\text {int }}$ \\
\hline 1991 & 0.53 & 0.81 & -0.08 & -0.20 \\
1992 & 0.10 & 0.15 & 0.17 & -0.22 \\
1993 & 1.01 & 0.99 & 0.36 & -0.34 \\
1994 & 0.01 & 0.50 & 0.01 & -0.50 \\
1995 & 0.67 & -0.03 & 0.41 & 0.29 \\
1996 & -0.16 & -0.25 & -0.32 & 0.41 \\
1997 & 0.08 & 0.00 & 0.26 & -0.18 \\
1998 & 0.85 & 0.34 & 0.13 & 0.38 \\
1999 & 1.10 & 0.09 & 0.96 & 0.05 \\
2000 & 1.32 & 0.15 & 0.61 & 0.56 \\
2001 & 0.83 & 1.06 & 0.04 & -0.27 \\
2002 & 0.39 & 0.18 & 0.41 & -0.20 \\
2003 & 0.22 & 0.73 & -0.28 & -0.23 \\
2004 & 1.02 & 0.35 & 0.57 & 0.10 \\
2005 & 0.49 & -0.22 & 0.47 & 0.24 \\
2006 & 0.47 & -0.29 & 0.74 & 0.02 \\
2007 & 0.93 & 0.19 & 0.38 & 0.36 \\
2008 & 2.08 & 0.49 & 0.59 & 1.00 \\
2009 & 1.73 & 0.58 & 0.33 & 0.82 \\
2010 & -1.6 & 0.03 & -0.94 & -0.69 \\
2011 & 0.07 & -0.01 & 0.17 & -0.09 \\
2012 & 0.72 & -0.04 & 0.43 & 0.33 \\
2013 & -0.43 & -0.51 & 0.44 & -0.36 \\
2014 & 0.17 & -0.33 & 0.33 & 0.17 \\
2015 & 0.18 & -0.83 & 0.62 & 0.39 \\
\hline \hline
\end{tabular}

Note: This table presents changes between year $\mathrm{t}$ and year $\mathrm{t}-1$ in total misallocation and its three components in the French manufacturing sector. All changes are expressed in log points.

log-points lower because of the deterioration of allocational efficiency. In other terms, 2007's aggregate TFP would have been almost $8 \%$ higher $\left(e^{10 * 0.0076}-1\right)$ if misallocation had remained to its 1997 level. The interplay component is roughly stable over this period, and does not contribute to this increase. The rise of misallocation is mainly related to an increase of labor misallocation, except at the beginning of the 2000s: from 2000 to 2004, total misallocation increases by 0.61 log-points per year, while capital misallocation represents by itself an annual rise of 0.58 log-points. This empirical finding reminds those of Gopinath et al. (2017), who argue that the decline in the real interest rate attributed to the euro convergence process lead to an increase in capital misallocation in Southern Europe countries, as capital inflows were oriented to firms with high net worth but not necessarily high productivity. ${ }^{28}$ Although this

\footnotetext{
${ }^{28}$ However, and surprisingly, Gopinath et al. (2017) find no deterioration of allocational efficiency for the french manufacturing sector between 2000 and 2012; this is all the more surprising given that one would have
} 
paper does not aim at providing empirical evidence highlighting the influence of this mechanism in the French manufacturing sector, Cette et al. (2016) use VAR models to show that shocks on interest rates negatively contributed to trends in French labor productivity, the effect being smaller than for Spain and Italy.

Unsurprisingly, figure 1 shows that the deterioration of allocational efficiency accelerated during the Great Recession. Misallocation culminated in 2009 before a sizable decrease in 2010. I find that it contributes for roughly $26 \%$ of the 2007-2009 drop in aggregate TFP I observe in my dataset, comparing with its pre-crisis trend, and for $20 \%$ of the 2010 recovery. Although financial frictions and capital misallocation are obvious suspects in order to link allocational efficiency and the large drop in aggregate productivity during the Great Recession (see for example Khan and Thomas (2013), Di Nola (2015)), I find that the main feature of the 20072009 episode is the impact of the interplay between labor and capital distortions. It accounts for almost half of the surge in total misallocation, while the capital and labor components accounts for roughly $25 \%$ each.

Finally, misallocation is rather stable from 2010 to 2015. I find no deterioration or improvement, although it appears that capital misallocation decreases and compensates an increase in labor misallocation. As a consequence one can hardly consider allocational efficiency as a driver of the low TFP growth in the wake of the Great Recession, at least in the French manufacturing sector. Actually the difference between the pre-2007 and the post-2010 growth rate is even higher for efficient TFP than for actual TFP: focusing on productivity at the firm-level may therefore shed more light on aggregate TFP slowdown than the efficiency of factors allocation.

\section{Robustness checks}

In this section I perform the following robustness checks:

- I shut down the entry-exit channel by focusing only on incumbent firms ${ }^{29}$

- I measure physical productivity using as labor input the wage bill declared by the firm, in order to control for the quality of the workforce and for the quantity of hours worked per employee

expected the Great Recession to have a sizable impact on misallocation.

${ }^{29}$ More precisely, I estimate the change in log-misallocation between year $\mathrm{t}$ and year $\mathrm{t}+1$ by keeping only firms in activity at both $\mathrm{t}$ and $\mathrm{t}+1$. 
- I define sectors at the 2-digit level rather than at the 3-digit level

- I measure the parameters of the Cobb-Douglas aggregator by sectors' average weights, in order to make sure that changes in allocational efficiency are not driven by highmisallocation industries getting a higher/lower relative weight over time

- Finally, I assume that the gross output production function is Leontieff in materials in order to estimate sector-specific elasticities of substitution (see Appendix B for details on the econometric methodology)

All figures and tables describing the evolution of misallocation and of its components for the various robustness checks can be found in Appendix C.

In all cases misallocation clearly follows an increasing trend during the decade preceding the Great Recession: the annual loss in TFP growth due to the deterioration of allocational efficiency goes from 0.67 (focusing on incumbent firms) to 0.88 log-points (defining sectors at the two-digit level). At the beginning of the 2000's capital misallocation is the main driver of total misallocation, while labor misallocation is the main contributor the rest of the 19972007 decade. The interplay component remains stable until 2007, but increases sharply from 2007 to 2009: it is the first contributor to the rise in misallocation during the Great Recession, whatever the specification. Total misallocation culminates in 2009 and decreases sharply in 2010. Its contribution to the 2007-2009 drop in aggregate TFP (comparing with the precrisis trend) is comprised between $23 \%$ (sectors defined at the 2-digit level) and $31 \%$ (sectorspecific elasticities), while it accounts for $17 \%$ (sector-specific elasticities) to $26 \%$ (constant sectoral weights) of the 2010 recovery. Finally, in all cases post-crisis misallocation is quite flat, changes in labor misallocation and changes in capital misallocation compensating each other. These observations therefore corroborate the empirical results I obtained with the baseline specification.

\section{Conclusion}

In this paper I measure the contribution of resource misallocation to the variations in aggregate productivity from 1990 to 2015 in the French manufacturing sector. I provide an exact decomposition of allocational efficiency between three components: labor misallocation, capi- 
tal misallocation, and the interplay between both types of misallocation. During the decade preceding the Great Recession misallocation worsen over time, creating an annual loss in TFP growth comprised between 0.67 and 0.88 log-points. Labor misallocation is the main driver of this rise, except at the beginning of the 2000s, capital misallocation being in this case the main contributor. The specificity of allocational efficiency during the Great Recession is that the interplay component plays a major role, while it remains flat the rest of the time. This empirical feature suggests that one should pay special attention to mechanisms disrupting both labor and capital markets during financial crisis, as capital misallocation does not by itself account for the bulk of misallocation during the Great Recession. The deterioration of allocational efficiency is found to explain 23 to $31 \%$ of the 2007-2009 drop in aggregate TFP, comparing to its pre-crisis trend, while the decrease in misallocation accounts for 17 to $26 \%$ of the 2010 recovery. Finally, misallocation is stable after 2010, although an increase in labor misallocation is compensated by an decrease in capital misallocation. The post-crisis slowdown in efficient TFP is therefore even higher than the slowdown in observed TFP; as a result one could shed light on the debate surrounding the behaviour of post-crisis productivity by focusing on within-firm TFP. 


\section{Appendix A. The log-normality assumption}

From equation (21) one can show that:

$$
\begin{gathered}
\ln \left(\frac{T F P_{s}^{*}}{T F P_{s}}\right)=\frac{1}{\rho_{s}-1} \ln \left(\frac{1}{n_{s}} \sum_{i=1}^{n_{s}} e^{\left(\rho_{s}-1\right) \ln \left(z_{i s}\right)}\right) \\
-\frac{\rho_{s}}{\rho_{s}-1} \ln \left(\frac{1}{n_{s}} \sum_{i=1}^{n_{s}} e^{\left(\rho_{s}-1\right) \ln \left(z_{i s}\right)+\left(1-\rho_{s}\right) \alpha_{s} \ln \left(1+\tau_{i s}^{k}\right)+\left(1-\rho_{s}\right)\left(1-\alpha_{s}\right) \ln \left(1+\tau_{i s}^{l}\right)}\right) \\
+\alpha_{s} \ln \left(\frac{1}{n_{s}} \sum_{i=1}^{n_{s}} e^{\left(\rho_{s}-1\right) \ln \left(z_{i s}\right)+\left(\left(1-\rho_{s}\right) \alpha_{s}-1\right) \ln \left(1+\tau_{i s}^{k}\right)+\left(1-\rho_{s}\right)\left(1-\alpha_{s}\right) \ln \left(1+\tau_{i s}^{l}\right)}\right) \\
+\left(1-\alpha_{s}\right) \ln \left(\frac{1}{n_{s}} \sum_{i=1}^{n_{s}} e^{\left(\rho_{s}-1\right) \ln \left(z_{i s}\right)+\left(1-\rho_{s}\right) \alpha_{s} \ln \left(1+\tau_{i s}^{k}\right)+\left(\left(1-\rho_{s}\right)\left(1-\alpha_{s}\right)-1\right) \ln \left(1+\tau_{i s}^{l}\right)}\right)
\end{gathered}
$$

Assuming that $n_{s}$ tends to infinity, the law of large numbers states that

$$
\frac{1}{n_{s}} \sum_{i=1}^{n_{s}} e^{\alpha \ln \left(z_{i s}\right)+\beta \ln \left(1+\tau_{i s}^{k}\right)+\gamma \ln \left(1+\tau_{i s}^{l}\right)} \underset{n_{s} \rightarrow \infty}{\stackrel{a . s .}{\longrightarrow}} \mathbb{E}\left[e^{\alpha \ln \left(z_{s}\right)+\beta \ln \left(1+\tau_{s}^{k}\right)+\gamma \ln \left(1+\tau_{s}^{l}\right)}\right]
$$

Under the assumption that idiosyncratic productivity, capital distortion and labor distortion are jointly $\log$-normal within each sector, the vector $\mathrm{X}=\left(\ln \left(z_{s}\right), \ln \left(1+\tau_{s}^{k}\right), \ln \left(1+\tau_{s}^{l}\right)\right)$ follows a multivariate normal distribution. Therefore its moment-generating function writes :

$$
\mathbb{E}\left[e^{t^{\prime} X}\right]=e^{t^{\prime} \nu+\frac{1}{2} t^{\prime} \Sigma t}
$$

where $\nu$ is the mean vector and $\Sigma$ is the covariance matrix. Applying this formula to equation (27) we get that:

$$
\begin{aligned}
\ln \left(\frac{T F P_{s}^{*}}{T F P_{s}}\right) \underset{n_{s} \rightarrow \infty}{\stackrel{a . s .}{\longrightarrow}} \frac{1}{2} \alpha_{s}\left(1+\alpha_{s}\left(\rho_{s}-1\right)\right) \operatorname{Var}\left[\ln \left(1+\tau_{s}^{k}\right)\right] \\
+\frac{1}{2}\left(1-\alpha_{s}\right)\left(1+\left(1-\alpha_{s}\right)\left(\rho_{s}-1\right)\right) \operatorname{Var}\left[\ln \left(1+\tau_{s}^{l}\right)\right] \\
\quad+\alpha_{s}\left(1-\alpha_{s}\right)\left(\rho_{s}-1\right) \operatorname{Cov}\left[\ln \left(1+\tau_{s}^{k}\right), \ln \left(1+\tau_{s}^{l}\right)\right]
\end{aligned}
$$


Applying the same formula to each part of equation (26) we get that:

$$
\begin{gathered}
\ln \left(M_{s, k}\right) \underset{n_{s} \rightarrow \infty}{\stackrel{a . s .}{\longrightarrow}} \frac{1}{2} \alpha_{s}\left(1+\alpha_{s}\left(\rho_{s}-1\right)\right) \operatorname{Var}\left[\ln \left(1+\tau_{s}^{k}\right)\right] \\
\ln \left(M_{s, l}\right) \underset{n_{s} \rightarrow \infty}{\stackrel{a . s .}{\longrightarrow}} \frac{1}{2}\left(1-\alpha_{s}\right)\left(1+\left(1-\alpha_{s}\right)\left(\rho_{s}-1\right)\right) \operatorname{Var}\left[\ln \left(1+\tau_{s}^{l}\right)\right] \\
\ln \left(M_{s, \text { int }}\right)=\ln \left(M_{s}\right)-\ln \left(M_{s, k}\right)-\ln \left(M_{s, l}\right) \underset{n_{s} \rightarrow \infty}{\stackrel{a . s .}{\longrightarrow}} \alpha_{s}\left(1-\alpha_{s}\right)\left(\rho_{s}-1\right) \operatorname{Cov}\left[\ln \left(1+\tau_{s}^{k}\right), \ln \left(1+\tau_{s}^{l}\right)\right]
\end{gathered}
$$

\section{Appendix B. Estimating sector-specific elasticities of substitu- tion}

De Loecker (2011) proposes a flexible approach to recover firm-level markups while relying on production data. With this approach markups are obtained by simply multiplying the output elasticity of a variable input (i.e., that can freely be adjusted) by this input's inverse revenue share. In my framework capital and labor are hardly supposed to be freely adjustable, as distortions drive marginal revenue products away from the optimal level. Therefore I use a closely related approach, with materials as the variable input. A rather standard approach in the literature ${ }^{30}$ to justify the use of value added production functions relies on the assumption that firms use intermediate inputs in fixed proportion to output (that is to say, the gross output production function is Leontieff in materials):

$$
Q_{i s t}=\min \left\{z_{i s t} k_{i s t}^{\alpha_{s}} l_{i s t}^{1-\alpha_{s}}, \frac{m_{i s t}}{1-c_{s}}\right\}
$$

Therefore at the optimum value added and materials are proportional:

$$
\begin{gathered}
m_{i s t}=\left(1-c_{s}\right) z_{i s t} k_{i s t}^{\alpha_{s}} l_{i s t}^{1-\alpha_{s}} \\
Q_{i s t}-m_{i s t}=y_{i s t}=\frac{c_{s}}{1-c_{s}} m_{i s t}
\end{gathered}
$$

I slightly modify the demand equation to allow for demand shocks, and I assume that those shocks consist of a firm-invariant (but sector-specific) time effect, a time-invariant individual effect, and an idiosyncratic shock which cannot be anticipated by the firm and does not impact

\footnotetext{
${ }^{30}$ See for example Rotemberg and Woodford (1993).
} 
its inputs decisions:

$$
\begin{gathered}
\frac{y_{i s t}}{Y_{s t}}=\left(\frac{p_{i s t}}{P_{s t}}\right)^{-\rho_{s}} d_{i s t}^{\rho_{s}} \\
\ln \left(d_{i s t}\right)=u_{s t}+v_{i s}+\epsilon_{i s t}
\end{gathered}
$$

Under such assumptions we get that:

$$
\ln \left(p_{i s t} y_{i s t}\right)=\frac{\rho_{s}-1}{\rho_{s}} \ln \left(\frac{c_{s}}{1-c_{s}}\right)+\frac{\rho_{s}-1}{\rho_{s}} \ln \left(m_{i s t}\right)+\ln \left(P_{s t} Y_{s t}^{\frac{1}{\rho_{s}}}\right)+u_{s t}+v_{i s}+\epsilon_{i s t}
$$

Therefore for each sector I estimate the elasticity of substitution by regressing log-nominal value added on the log of materials, allowing for a time fixed-effect and a firm fixed-effect. Defining sectors at the three-digit level I estimate 85 elasticities of substitution; the average elasticity and the median elasticity are respectively equal to 3.2 and 3.1, therefore very close to the initial specification. The min elasticity is 1.8, the max 7.6, Q1 and Q3 are respectively equal to 2.7 and 3.5 .

\section{Appendix C. Robustness checks}

Figure 2: Variation of misallocation over time, shutting down the entry-exit channel

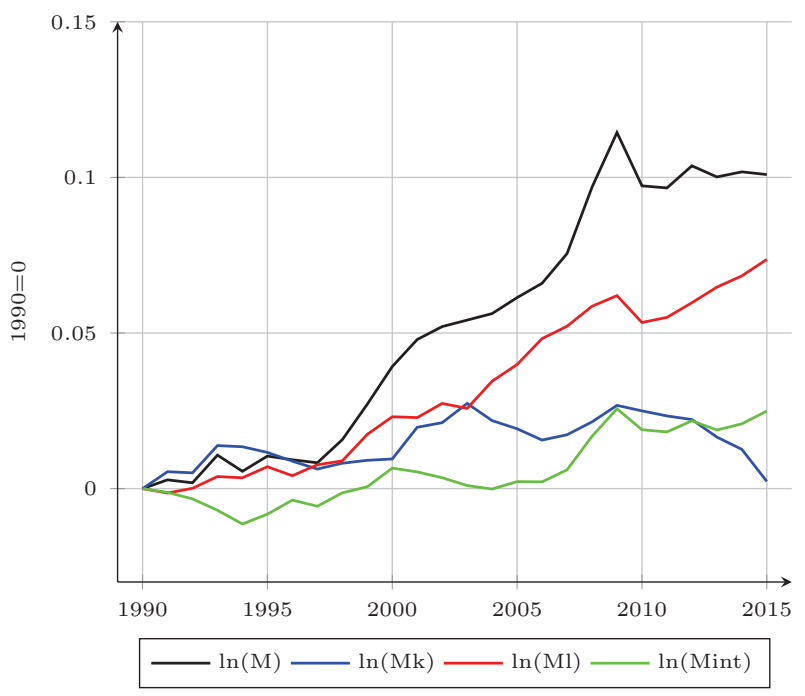

Note: This figure presents variations of aggregate misallocation and its three components over time in the French manufacturing sector. I shut down the entry-exit channel by focusing on incumbent firms. All series are in logs with 1990 normalized to 0. 
Figure 3: Variation of misallocation over time, using wage bills to measure productivity

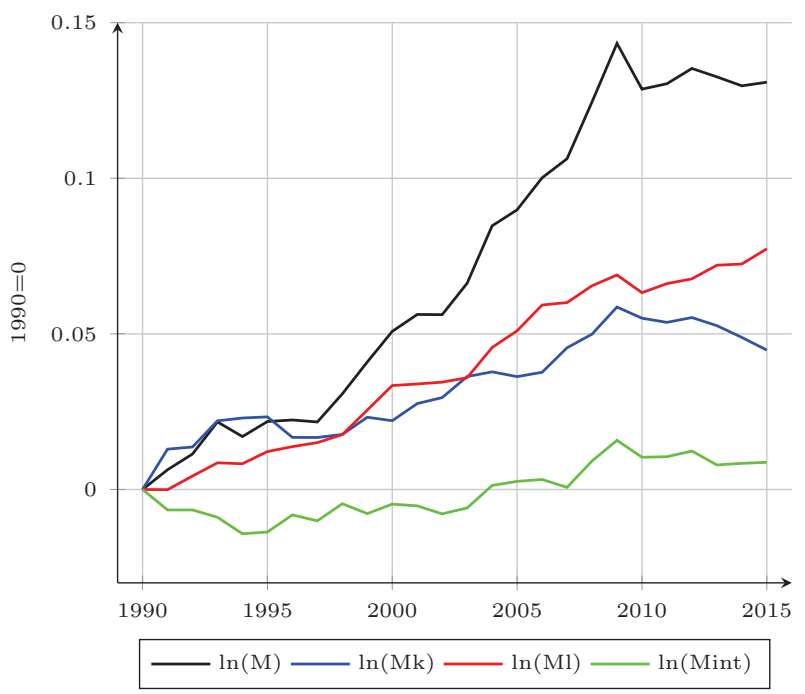

Note: This figure presents variations of aggregate misallocation and its three components over time in the French manufacturing sector. I measure physical productivity using as labor input the wage bill declared by the firm. All series are in logs with 1990 normalized to 0.

Figure 4: Variation of misallocation over time, defining sectors at the 2-digits level

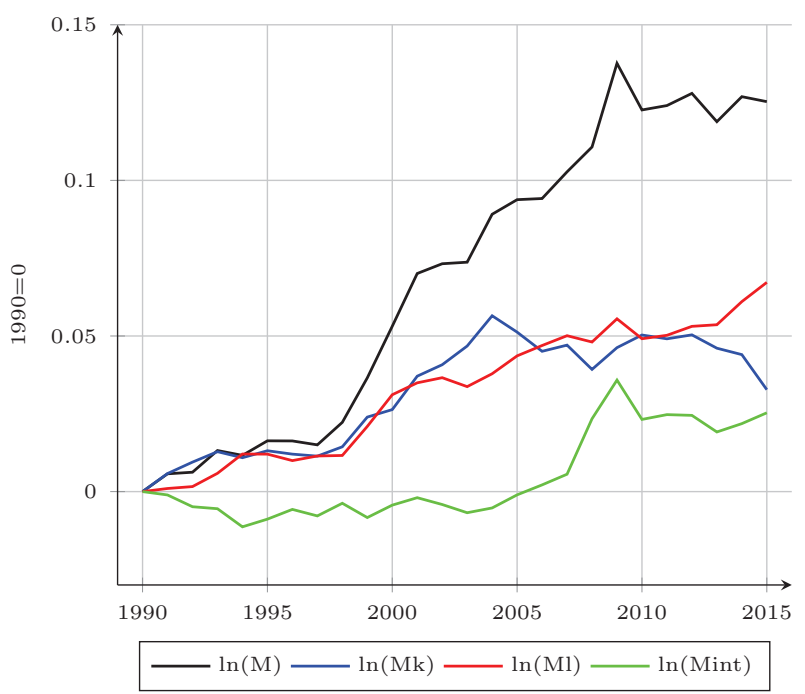

Note: This figure presents variations of aggregate misallocation and its three components over time in the French manufacturing sector. I define sectors at the two-digits level. All series are in logs with 1990 normalized to 0. 
Figure 5: Variation of misallocation over time, keeping sectoral weights constant

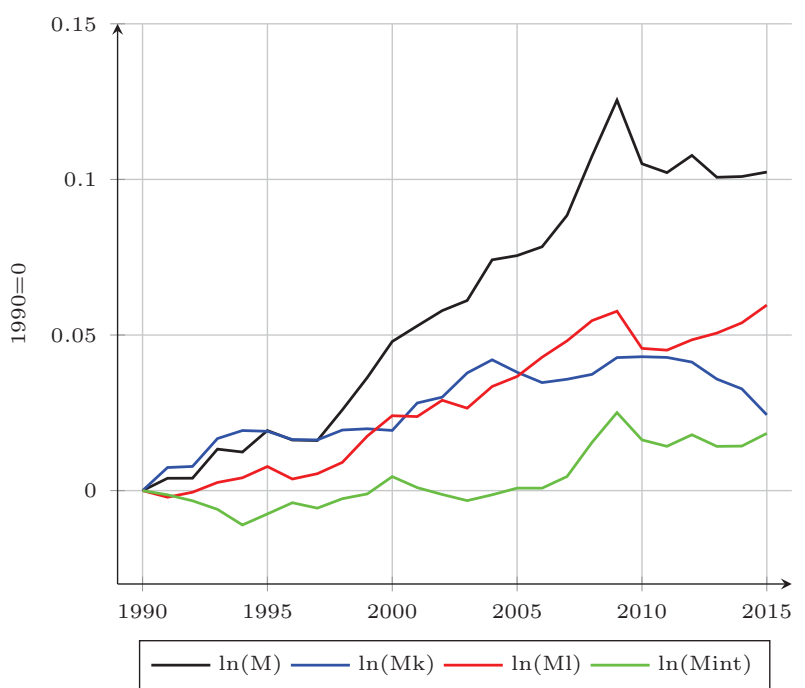

Note: This figure presents variations of aggregate misallocation and its three components over time in the French manufacturing sector. Sectoral weights are kept constant over time and set to their mean. All series are in logs with 1990 normalized to 0.

Figure 6: Variation of misallocation over time, using sector-specific elasticities

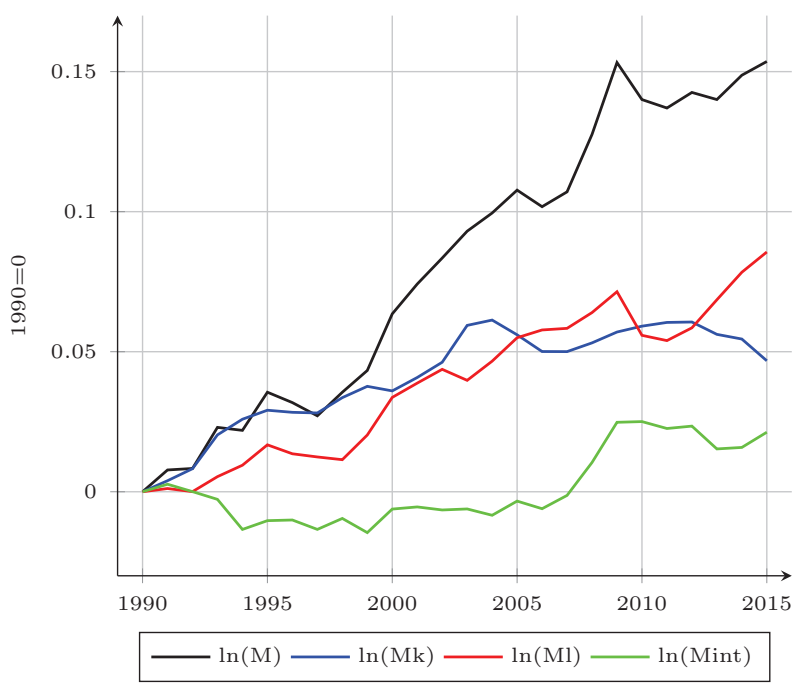

Note: This figure presents variations of aggregate misallocation and its three components over time in the French manufacturing sector. I estimate and use in my computations sector-specific elasticities of substitution. All series are in logs with 1990 normalized to 0. 
Table 7: Changes in total misallocation and in its three components, shutting down the entryexit channel

\begin{tabular}{lcccc}
\hline \hline & $\Delta M$ & $\Delta M_{k}$ & $\Delta M_{l}$ & $\Delta M_{\text {int }}$ \\
\hline 1991 & 0.28 & 0.54 & -0.14 & -0.12 \\
1992 & -0.10 & -0.04 & 0.15 & -0.21 \\
1993 & 0.89 & 0.88 & 0.38 & -0.37 \\
1994 & -0.52 & -0.04 & -0.04 & -0.44 \\
1995 & 0.49 & -0.18 & 0.35 & 0.32 \\
1996 & -0.12 & -0.28 & -0.29 & 0.45 \\
1997 & -0.10 & -0.25 & 0.35 & -0.20 \\
1998 & 0.74 & 0.19 & 0.12 & 0.43 \\
1999 & 1.14 & 0.09 & 0.85 & 0.20 \\
2000 & 1.21 & 0.04 & 0.57 & 0.60 \\
2001 & 0.87 & 1.02 & -0.03 & -0.12 \\
2002 & 0.41 & 0.15 & 0.45 & -0.19 \\
2003 & 0.21 & 0.62 & -0.16 & -0.25 \\
2004 & 0.21 & -0.55 & 0.87 & -0.11 \\
2005 & 0.51 & -0.26 & 0.53 & 0.24 \\
2006 & 0.46 & -0.36 & 0.83 & -0.01 \\
2007 & 0.96 & 0.17 & 0.40 & 0.39 \\
2008 & 2.13 & 0.41 & 0.64 & 1.08 \\
2009 & 1.76 & 0.53 & 0.34 & 0.89 \\
2010 & -1.71 & -0.18 & -0.86 & -0.67 \\
2011 & -0.07 & -0.16 & 0.16 & -0.07 \\
2012 & 0.71 & -0.12 & 0.47 & 0.36 \\
2013 & -0.36 & -0.56 & 0.50 & -0.30 \\
2014 & 0.16 & -0.39 & 0.36 & 0.19 \\
2015 & -0.09 & -1.03 & 0.53 & 0.41 \\
\hline \hline
\end{tabular}

Note: This table presents changes between year $\mathrm{t}$ and year $\mathrm{t}-1$ in total misallocation and its three components in the French manufacturing sector. I shut down the entry-exit channel by focusing on incumbent firms. All changes are expressed in log points. 
Table 8: Changes in total misallocation and in its three components, using wage bills to measure productivity

\begin{tabular}{lcccc}
\hline \hline & $\Delta M$ & $\Delta M_{k}$ & $\Delta M_{l}$ & $\Delta M_{\text {int }}$ \\
\hline 1991 & 0.63 & 1.30 & -0.01 & -0.66 \\
1992 & 0.51 & 0.07 & 0.44 & 0.00 \\
1993 & 1.03 & 0.84 & 0.42 & -0.23 \\
1994 & -0.47 & 0.09 & -0.03 & -0.53 \\
1995 & 0.48 & 0.04 & 0.39 & 0.05 \\
1996 & 0.05 & -0.66 & 0.16 & 0.55 \\
1997 & -0.06 & 0.00 & 0.13 & -0.19 \\
1998 & 0.90 & 0.10 & 0.25 & 0.55 \\
1999 & 1.02 & 0.55 & 0.79 & -0.32 \\
2000 & 0.98 & -0.11 & 0.79 & 0.30 \\
2001 & 0.54 & 0.55 & 0.05 & -0.06 \\
2002 & -0.01 & 0.19 & 0.06 & -0.26 \\
2003 & 1.01 & 0.68 & 0.14 & 0.19 \\
2004 & 1.84 & 0.15 & 0.97 & 0.72 \\
2005 & 0.52 & -0.15 & 0.54 & 0.13 \\
2006 & 1.03 & 0.14 & 0.83 & 0.06 \\
2007 & 0.62 & 0.79 & 0.08 & -0.25 \\
2008 & 1.83 & 0.44 & 0.54 & 0.85 \\
2009 & 1.88 & 0.87 & 0.35 & 0.66 \\
2010 & -1.47 & -0.36 & -0.57 & -0.54 \\
2011 & 0.18 & -0.13 & 0.29 & 0.02 \\
2012 & 0.49 & 0.16 & 0.15 & 0.18 \\
2013 & -0.27 & -0.26 & 0.44 & -0.45 \\
2014 & -0.29 & -0.38 & 0.04 & 0.05 \\
2015 & 0.12 & -0.41 & 0.49 & 0.04 \\
\hline \hline
\end{tabular}

Note: This table presents changes between year $\mathrm{t}$ and year $\mathrm{t}-1$ in total misallocation and its three components in the French manufacturing sector. I measure physical productivity using as labor input the wage bill declared by the firm. All changes are expressed in log points. 
Table 9: Changes in total misallocation and in its three components, defining sectors at the 2-digits level

\begin{tabular}{|c|c|c|c|c|}
\hline & $\Delta M$ & $\Delta M_{k}$ & $\Delta M_{l}$ & $\Delta M_{i n t}$ \\
\hline 1991 & 0.57 & 0.58 & 0.10 & -0.11 \\
\hline 1992 & 0.05 & 0.37 & 0.06 & -0.38 \\
\hline 1993 & 0.70 & 0.33 & 0.43 & -0.06 \\
\hline 1994 & -0.15 & -0.19 & 0.62 & -0.58 \\
\hline 1995 & 0.47 & 0.22 & 0.00 & 0.25 \\
\hline 1996 & -0.01 & -0.11 & -0.21 & 0.31 \\
\hline 1997 & -0.13 & -0.07 & 0.15 & -0.21 \\
\hline 1998 & 0.73 & 0.30 & 0.02 & 0.41 \\
\hline 1999 & 1.43 & 0.96 & 0.93 & -0.46 \\
\hline 2000 & 1.66 & 0.24 & 1.02 & 0.40 \\
\hline 2001 & 1.69 & 1.07 & 0.38 & 0.24 \\
\hline 2002 & 0.31 & 0.37 & 0.16 & -0.22 \\
\hline 2003 & 0.05 & 0.60 & -0.29 & -0.26 \\
\hline 2004 & 1.54 & 0.97 & 0.42 & 0.15 \\
\hline 2005 & 0.47 & -0.52 & 0.57 & 0.42 \\
\hline 2006 & 0.03 & -0.62 & 0.33 & 0.32 \\
\hline 2007 & 0.86 & 0.20 & 0.32 & 0.34 \\
\hline 2008 & 0.80 & -0.78 & -0.20 & 1.78 \\
\hline 2009 & 2.69 & 0.70 & 0.75 & 1.24 \\
\hline 2010 & -1.50 & 0.40 & -0.64 & -1.26 \\
\hline 2011 & 0.14 & -0.12 & 0.11 & 0.15 \\
\hline 2012 & 0.39 & 0.13 & 0.29 & -0.03 \\
\hline 2013 & -0.91 & -0.43 & 0.05 & -0.53 \\
\hline 2014 & 0.80 & -0.21 & 0.74 & 0.27 \\
\hline 2015 & -0.16 & -1.13 & 0.62 & 0.35 \\
\hline
\end{tabular}

Note: This table presents changes between year $\mathrm{t}$ and year $\mathrm{t}-1$ in total misallocation and its three components in the French manufacturing sector. I define sectors at the two-digits level. All changes are expressed in log points. 
Table 10: Changes in total misallocation and in its three components, keeping sectoral weights constant

\begin{tabular}{lcccc}
\hline \hline & $\Delta M$ & $\Delta M_{k}$ & $\Delta M_{l}$ & $\Delta M_{\text {int }}$ \\
\hline 1991 & 0.40 & 0.74 & -0.21 & -0.13 \\
1992 & 0.00 & 0.03 & 0.16 & -0.19 \\
1993 & 0.93 & 0.90 & 0.31 & -0.28 \\
1994 & -0.09 & 0.26 & 0.15 & -0.50 \\
1995 & 0.69 & -0.02 & 0.36 & 0.35 \\
1996 & -0.31 & -0.27 & -0.40 & 0.36 \\
1997 & -0.01 & -0.01 & 0.17 & -0.17 \\
1998 & 0.98 & 0.32 & 0.36 & 0.30 \\
1999 & 1.04 & 0.04 & 0.85 & 0.15 \\
2000 & 1.16 & -0.05 & 0.65 & 0.56 \\
2001 & 0.50 & 0.88 & -0.03 & -0.35 \\
2002 & 0.49 & 0.19 & 0.52 & -0.22 \\
2003 & 0.33 & 0.78 & -0.25 & -0.20 \\
2004 & 1.31 & 0.42 & 0.70 & 0.19 \\
2005 & 0.13 & -0.40 & 0.32 & 0.21 \\
2006 & 0.29 & -0.33 & 0.62 & 0.00 \\
2007 & 1.01 & 0.11 & 0.53 & 0.37 \\
2008 & 1.90 & 0.15 & 0.65 & 1.10 \\
2009 & 1.80 & 0.54 & 0.30 & 0.96 \\
2010 & -2.04 & 0.03 & -1.19 & -0.88 \\
2011 & -0.29 & -0.02 & -0.06 & -0.21 \\
2012 & 0.55 & -0.15 & 0.33 & 0.37 \\
2013 & -0.70 & -0.55 & 0.22 & -0.37 \\
2014 & 0.02 & -0.32 & 0.33 & 0.01 \\
2015 & 0.14 & -0.84 & 0.57 & 0.41 \\
\hline \hline
\end{tabular}

Note: This table presents changes between year $\mathrm{t}$ and year $\mathrm{t}-1$ in total misallocation and its three components in the French manufacturing sector. Sectoral weights are kept constant over time and set to their mean. All changes are expressed in log points. 
Table 11: Changes in total misallocation and in its three components, using sector-specific elasticities

\begin{tabular}{lcccc}
\hline \hline & $\Delta M$ & $\Delta M_{k}$ & $\Delta M_{l}$ & $\Delta M_{\text {int }}$ \\
\hline 1991 & 0.78 & 0.39 & 0.12 & 0.27 \\
1992 & 0.05 & 0.43 & -0.11 & -0.27 \\
1993 & 1.47 & 1.21 & 0.54 & -0.28 \\
1994 & -0.11 & 0.56 & 0.41 & -1.08 \\
1995 & 1.36 & 0.32 & 0.73 & 0.31 \\
1996 & -0.37 & -0.07 & -0.32 & 0.02 \\
1997 & -0.47 & -0.02 & -0.11 & -0.34 \\
1998 & 0.84 & 0.55 & -0.10 & 0.39 \\
1999 & 0.78 & 0.40 & 0.88 & -0.50 \\
2000 & 2.02 & -0.16 & 1.34 & 0.84 \\
2001 & 1.07 & 0.48 & 0.51 & 0.08 \\
2002 & 0.93 & 0.55 & 0.49 & -0.11 \\
2003 & 0.96 & 1.31 & -0.39 & 0.04 \\
2004 & 0.65 & 0.19 & 0.69 & -0.23 \\
2005 & 0.82 & -0.53 & 0.84 & 0.51 \\
2006 & -0.59 & -0.60 & 0.28 & -0.27 \\
2007 & 0.53 & 0.00 & 0.06 & 0.47 \\
2008 & 2.05 & 0.31 & 0.56 & 1.18 \\
2009 & 2.57 & 0.39 & 0.74 & 1.44 \\
2010 & -1.32 & 0.21 & -1.56 & 0.03 \\
2011 & -0.30 & 0.13 & -0.19 & -0.24 \\
2012 & 0.56 & 0.01 & 0.46 & 0.09 \\
2013 & -0.25 & -0.44 & 1.00 & -0.81 \\
2014 & 0.87 & -0.16 & 0.98 & 0.05 \\
2015 & 0.49 & -0.77 & 0.72 & 0.54 \\
\hline \hline
\end{tabular}

Note: This table presents changes between year $\mathrm{t}$ and year $\mathrm{t}-1$ in total misallocation and its three components in the French manufacturing sector. I estimate and use in my computations sector-specific elasticities of substitution. All changes are expressed in log points. 


\section{References}

Anzoategui, D. et al. (2016). "Endogenous technology adoption and R\&D as sources of business cycle persistence". NBER Working Paper 22005.

Asker, J., A. Collard-Wexler, and J. De Loecker (2014). "Dynamic inputs and resource (mis)allocation". Journal of Political Economy 122.5, pp. 1013-1063.

Banerjee, A. and E. Duflo (2005). "Growth theory through the lens of development economics". In: Handbook of Economic Growth. Ed. by P.Aghion and S.Durlauf. Amsterdam: Elsevier, pp. $473-552$.

Bellone, F. and J. Mallen-Pisano (2013). "Is misallocation higher in France than in the United States?" GREDEG Working Paper 38.

Buera, F. and B. Moll (2015). "Aggregate implications of a credit crunch: the importance of heterogeneity". American Economic Journal: Macroeconomics 7.3, pp. 1-42.

Calligaris, S. (2015). "Misallocation and total factor productivity in Italy : evidence from firmlevel data". CEIS Working Paper 357.

Calvo, G., A. Izquierdo, and E. Talvi (2006). "Sudden stops and phoenix miracles in emerging markets". American Economic Review 96.2, pp. 405-410.

Cette, G., J. Fernald, and B. Mojon (2016). "The Pre-Great Recession slowdown in productivity". European Economic Review 88.C, pp. 3-20.

Challe, E., J.I. Lopez, and E. Mengus (2016). "Southern Europe's institutional decline". Working Papers hal-01331723.

Chen, K. and A. Irarrazabal (2015). "The role of allocative efficiency in a decade of recovery". Review of Economic Dynamics 18.3, pp. 523-550.

Christiano, L., M. Eichenbaum, and M. Trabandt (2015). "Understanding the Great Recession". American Economic Journal : Macroeconomics 7.1, pp. 110-167.

De Loecker, J. (2011). "Recovering markups from production data". International Journal of Industrial Organization 29.Special issue 37th EARIE, pp. 350-355.

Di Nola, A. (2015). "Capital misallocation during the Great Recession". MPRA Paper 68289.

Dias, D., C. Robalo, and C. Richmond (2015). "Misallocation and productivity in the lead up to the Eurozone crisis". International Finance Discussion Papers 1146.

Fernald, J.G. (2015). "Productivity and potential output before, during and after the Great Recession". NBER Macroeconomics annual 29.1, pp. 1-51.

Foster, L., J. Haltiwanger, and C. Syverson (2008). "Reallocation, firm Turnover, and efficiency: selection on productivity or profitability?" American Economic Review 98.1, pp. 394-435.

Garcia-Santana, M. et al. (2016). "Growing like Spain: 1995-2007". Bank of Spain Working Paper.

Gerth, F. and K. Otsu (2016). "A post-crisis slump in Europe : a business cycle accounting analysis". Studies in Economics 1606. 
Gilchrist, S., J.W. Sim, and E. Zakrajsek (2013). "Misallocation and financial market frictions : some direct evidence from the dispersion in borrowing costs". Review of Economic Dynamics 16.1, pp. $159-176$.

Gopinath, G. et al. (2017). "Capital Allocation and Productivity in South Europe". The Quarterly Journal of Economics, forthcoming.

Hsieh, C.T. and P.J. Klenow (2009). "Misallocation and manufacturing TFP in China and India". The Quaterly Journal of Economics 124.4, pp. 1403-1448.

Jones, C.I. (2013). "Misallocation, economic growth and input-output economics". In: Advances in economics and econometrics, Tenth world congress, applied economics. Ed. by M.Arellano D.Acemoglu and E.Dekel. Cambridge University Press, pp. 419-456.

Kehoe, T. and E. Prescott (2002). "Great depressions of the 20th century". Review of Economic Dynamics 5.1, pp. 1-18.

Khan, A. and J. Thomas (2013). "Credit shocks and aggregate fluctuations in an economy with production heterogeneity". Journal of Political Economy 121.6, pp. 1055-1107.

Larrain, M. and S. Stumpner (2017). "Capital account liberalization and aggregate productivity: the role of firm capital allocation". Journal of Finance, forthcoming.

Levinsohn, P. and A. Petrin (2003). "Estimating production functions using inputs to control for unobservables". Review of Economic Studies 70.2, pp. 317-341.

Midrigan, V. and D. Y. Xu (2014). "Finance and misallocation: evidence from plant-level data". American Economic Review 104.2, pp. 422-458.

Moll, B. (2014). "Productivity losses from financial frictions: can self-financing undo capital misallocation?" American Economic Review 104.10, pp. 3186-3221.

Oberfield, E. (2013). "Productivity and misallocation during a crisis: evidence from the Chilean crisis of 1982". Review of Economic Dynamics 16.1, pp. 100-119.

Olley, S. and A. Pakes (1996). "The dynamics of productivity in the telecommunications equipment industry". Econometrica 64.6, pp. 1263-1297.

Reifschneider, D., W. Wascher, and D. Wilcox (2015). "Aggregate supply in the United States". IMF Economic Review 63.1, pp. 71-109.

Reis, R. (2013). "The Portuguese slump and crash and the Euro crisis". Brookings Papers on Economic Activity 46.1, pp. 143-210.

Restuccia, D. and R. Rogerson (2008). "Policy distorsions and aggregate productivity with heterogeneous establishments". Review of Economic Dynamics 11.4, pp. 707-720.

- (2013). "Misallocation and productivity". Review of Economic Dynamics 16.1, pp. 1-10.

Rotemberg, J. and M. Woodford (1993). "Dynamic general equilibrium models with imperfectly competitive product markets". NBER Working Paper 4502.

Sandleris, G. and M. Wright (2014). "The costs of financial crises: ressource misallocation, productivity and welfare in the 2001 Argentine Crisis". Scandinavian Journal of Economics 116.1, pp. 87-127. 
Sandoz, C. (2017). "Chinese import boom and TFP growth in France". mimeo.

Syverson, C. (2011). "What determines productivity?" Journal of Economic Literature 49.2, pp. 326-365.

Ziebarth, N. (2014). "Misallocation and productivity during the Great Depression". Northwestern university mimeo. 